by Xu Chen ${ }^{1}$, Jiayu Rong ${ }^{1}$, Junxuan Fan' ${ }^{1}$, Renbin Zhan ${ }^{1}$, Charles E. Mitchell ${ }^{2}$, David A.T. Harper ${ }^{3}$, Michael J. Melchin ${ }^{4}$, Ping'an Peng ${ }^{5}$, Stan C. Finney ${ }^{6}$, and Xiaofeng Wang ${ }^{7}$

\title{
The Global Boundary Stratotype Section and Point (GSSP) for the base of the Hirnantian Stage (the uppermost of the Ordovician System)
}

\footnotetext{
1. State Key Laboratory of Palaeobiology and Stratigraphy, Nanjing Institute of Geology and Palaeontology, Chinese Academy of Sciences, 39 East Beijing Road, Nanjing 210008, China.E-mails:xu1936@yahoo.com; jyrong@nigpas.ac.cn; fanjuanxuan@yahoo.com; rbzhan@nigpas.ac.cn

2. Department of Geology, the State University of New York at Buffalo, NY 14260-3050, USA. E-mail: cem@geology.buffalo.edu

3. Geological Museum, University of Copenhagen, Øster Voldgade 5-7, DK-1350 Copenhagen, Denmark. E-mail:dharper@savik.geomus.ku.dk

4. Department of Earth Sciences, St. Francis Xavier University, Antigonish, N.S. B2G 2W5, Canada. E-mail: mmelchin@stfx.ca

5. State Key Laboratory of Organic Geochemistry, Guangzhou Institute of Geochemistry, Chinese Academy of Sciences, Guangzhou 510640, China. E-mail: pinganp@gig.ac.cn

6. Department of Geological Sciences, California State University at Long Beach, Long Beach, CA 90840, USA. E-mail: scfinney@csulb.edu 7. Yichang Institute of Geology and Mineral Resources, 21 Gangyao Road, Yichang 443003, China. E-mail: ycwxiaofeng@yahoo.com.cn
}

The Global boundary Stratotype Section and Point (GSSP) for the base of the Hirnantian Stage (the uppermost of the Ordovician System) is defined at a point $0.39 \mathrm{~m}$ below the base of the Kuanyinchiao Bed in the Wangjiawan North section. The section is located near Wangjiawan village, $42 \mathrm{~km}$ north of Yichang city (west-

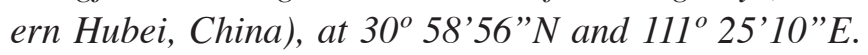
The GSSP level coincides with the first appearance of the graptolite species Normalograptus extraordinarius (Sobolevskaya). Secondary markers include the onset of a positive carbon-isotope excursion, and a slightly earlier first appearance of Normalograptus ojsuensis (Koren and Mikhailova). The Wangjiawan North section possesses continuity of sedimentation and biozonation with completeness of exposures, abundant and well-preserved graptolites and shelly fossils, i. e. the HirnantiaDalmanitina shelly fauna which is a key element for recognition of the Hirnantian Stage. The Wangjiawan North, South and Riverside sections possess favorable facies and widespread correlation potential, are free from structure complication, metamorphism and other alteration, and have good accessibility. The Riverside section in particular possesses amenability to isotopic age determination. The beginning of the Hirnantian was followed by a global episode of a major extinction event, which happened in the Diceratograptus mirus Subzone. The proposal was voted by the International Subcommission on Ordovician Stratigraphy in October, 2004, approved by the International Commission on Stratigraphy in February, 2006, and ratified by the International Union of Geological Sciences in May, 2006.

\section{Introduction}

The stratigraphic interval widely but informally recognized as the Hirnantian Stage includes the time interval of the latest Ordovician, and has a duration of a little less than 2 m.y. (Cooper and Sadler, 2004; Gradstein et al., 2004). In spite of its brief duration, this interval is very important. It records the second largest global extinction bioevent in Earth history. This mass extinction was associated with eustatic sea level fall and climatic cooling caused by expansion of a glacial ice sheet over the South Pole. As many as $85 \%$ of existing species became extinct during the time interval (Sheehan, 2001). These events are recorded by distinctive biostratigraphy, lithostratigraphy, sedimentology and chemostratigraphy that characterize stratigraphic successions representing the Hirnantian Stage worldwide. Formally establishing and defining the base of the Hirnantian Stage will provide the necessary frame of reference for precise global correlation, as well as a clear and consistent chronostratigraphic nomenclature for communication of research results pertaining to this time interval and the associated bioevents.

We propose that a stratigraphic level $0.39 \mathrm{~m}$ below the base of the Kuanyinchiao Bed in the Wangjiawan North section be designated as the Global Stratotype Section and Point (GSSP) for the Hirnantian Stage. At this level, the base of the Hirnantian Stage is coincident with the First Appearance Datum (FAD) of the graptolite Normalograptus extraordinarius (Sobolevskaya). The entire Hirnantian stratigraphic succession is well developed at Wangjiawan North, and the base of the Silurian, which forms the top of the Hirnantian Stage, is well studied from the Wangjiawan North section (Chen et al., 2003).

\section{Upper Ordovician Chronostratigraphy and the Hirnantian Stage}

In 2003, the base of the Upper Ordovician Series and its lower stage were ratified. The GSSP is at the level of the FAD of the graptolite Nemagraptus gracilis in the section at Fågelsång, Sweden (Bergström et al., 2000). Internal subdivision of the Upper Ordovician has proved problematic, however. In August, 2003, at the 9th International Symposium on the Ordovician System held in San 
Juan, Argentina, the Subcommission on Ordovician Stratigraphy voted overwhelmingly to abandon its goal of subdividing the Upper Ordovician Series into two stages. The Subcommission had been pursuing this strategy since 1995 (Webby, 1998). Subcommission members considered the base of the Dicellograptus complanatus graptolite zone and the base of the Amorphognathus ordovicicus conodont zone as the bioevents with the best potential for defining the base of the upper stage of the Upper Ordovician series (Webby, 1998) (Figure 1). In addition, some Ordovician workers chose to use the terms "Caradocian" and "Ashgillian" or Caradoc and Ashgill for these stages (Webby, 1998; Webby, 2004: Table 1.3). They considered them to be largely equivalent to the British Series that had been used as de facto global nomenclature on time scales and correlation charts. However, after evaluation of many sections worldwide, the Subcommission could not find any adequate boundary stratotype section based on the FAD of either D. complanatus or A. ordovicicus. In addition, Rickards' (2002) discovery of graptolites that he considers to be indicative of the Pleurograptus linearis Zone in strata within the upper part of the type Ashgill Series raised the possibility that much of the type Ashgill Series is actually co-eval with the upper part of the Caradoc Series, the top of which is also correlated with the P. linearis graptolite zone (Figure 1) (Fortey et al., 2000; Webby et al., 2004; Finney, 2005). The British Caradoc and Ashgill Series were defined on generally endemic benthic shelly faunas. Attempts to redefine them in terms of the graptolite zonation in order to use them as standards for global correlation proved unsuccessful (Fortey et al., 1995, 2000; Finney, 2005).

At the 9th International Symposium on the Ordovician System, Subcommission members decided upon a new approach: a three-fold

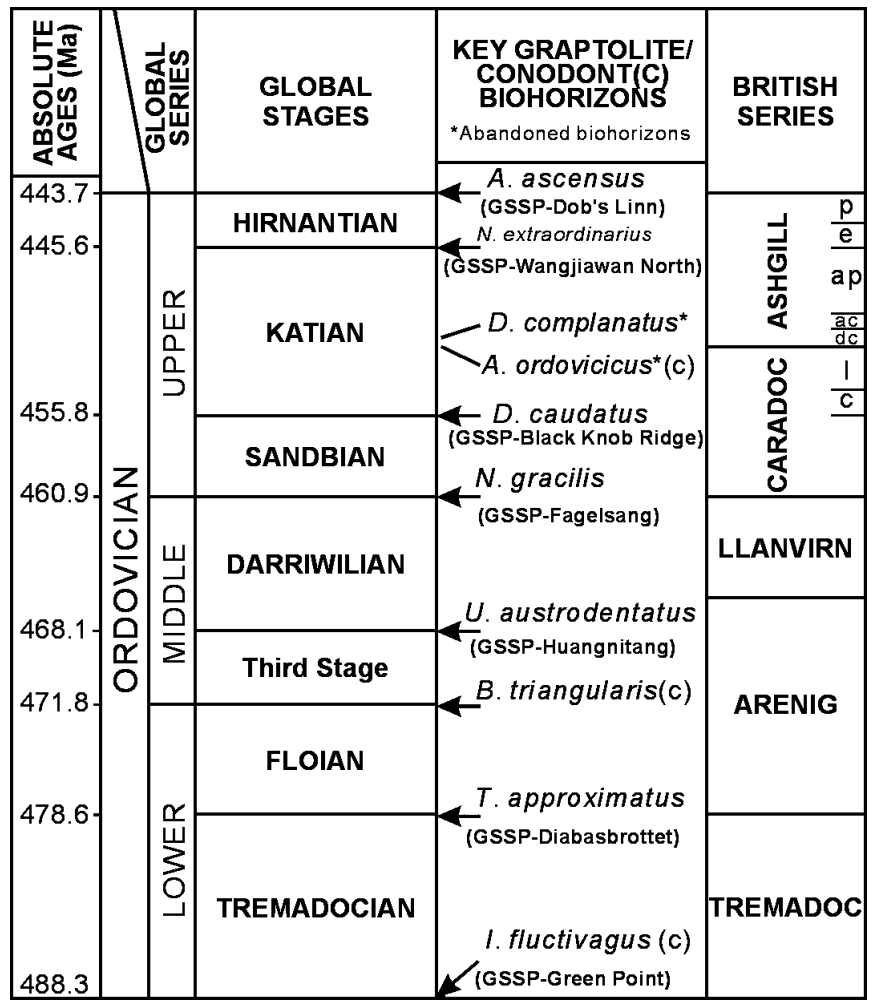

Figure 1 Time scale for the Ordovician System showing new global series and stages, and approved GSSPs. Regional British Series shown for comparison with graptolite zones in upper Caradoc and lower Ashgill shown by abbreviations: c-Dicranograptus clingani Zone; l-Pleurograptus linearis Zone; dc-Dicellograptus complanatus Zone; ac-Dicellograptus complexus Subzone of Dicellograptus anceps Zone; ap-Paraorthograptus pacificus Subzone of Dicellograptus anceps Zone; e-Normalograptus extraordinarius Zone; p-Normalograptus persculptus Zone (Modified from Finney, 2005, Figure 2). subdivision of the Upper Ordovician Series. Recent research by Goldman (2003) indicated that the FAD of the graptolite Diplacanthograptus caudatus was a reliable biohorizon for precise, global correlation, and the Black Knob Ridge section has been accepted by the Subcommission as the stratotype section for the base of the sixth Stage. However, because this boundary level results in two stages of very unequal duration (Figure 1), the suggestion that the Upper Ordovician Series be subdivided into three stages was overwhelmingly approved. The immediate acceptance of a third or uppermost stage was due to the fact that it would correspond to the informal, but widely used, Hirnantian Stage with its lower boundary defined at a level corresponding to the base of the $N$. extraordinarius graptolite zone (Finney, 2005).

The Hirnantian Stage was first defined as the uppermost stage of the British Ashgill Series, and it included a fauna of distinctive brachiopods and trilobites, the Hirnantia-Dalmanitina fauna (Temple, 1965). This fauna was found to have a worldwide distribution, and it was interpreted to be a mainly cool-water fauna, the dispersal of which reflected the dramatic, but short interval of glaciation at the end of the Ordovician Period (Berry and Boucot, 1973; Sheehan, 1973). Accordingly, the regional British Hirnantian Stage came to be associated with the Late Ordovician global climatic and associated biotic and eustatic events that were, thus, referred to as the Hirnantian glaciation. With a duration of $\sim 1.9$ m.y, the Hirnantian Stage is short, but not unusually short, and the corresponding Hirnantian Age was a time of dramatic events in Earth history - mass extinction and global climatic change with expansive glaciation and abrupt, substantial sea-level fall. It is recorded by distinctive paleontological, sedimentological, and chemostratigraphical records in stratigraphic successions of the Hirnantian Stage worldwide.

The term Hirnantian was first introduced by Bancroft (1933) as a regional stage name for the highest rocks in the Ordovician System at Bala, Wales. These included the Hirnant Limestone and associated sediments with a fauna dominated by the brachiopods 'Orthis' (i.e., Hirnantia) sagittifera M'Coy, 1851 and 'Rafinesquina' (i.e., Eostropheodonta) hirnantensis Temple, 1965. Bassett et al. (1966) revised this part of the succession, and included the Hirnant Limestone within their Foel-y-Ddinas Mudstones. Ingham and Wright (1970) proposed that the term Hirnantian should be revised and redefined to include the entire Foel-y-Ddinas Mudstones (sensu Bassett et al., 1966) noting the distinctive fauna of the unit, essentially the Hirnantia Fauna of current usage, including the brachiopods Dalmanella, Eostropheodonta, Hirnantia, Kinnella and Plectothyrella together with the trilobite Dalmanitina. Both the Hirnantia faunabearing beds (Whittington and Williams, 1964) and the Hirnantia Fauna have been reported and described from many parts of the world (Temple, 1965; Marek and Havlíč ek, 1967; Wright, 1968; Bergström, 1968; Williams et al., 1972; Lespérance and Sheehan, 1976; Rong, 1979, 1984a; Harper, 1981; Benedetto, 1986; Rong and Harper, 1988; Leone et al., 1991; Cocks and Fortey, 1997; Villas et al., 1999; Sutcliffe et al., 2001).

The Late Ordovician glaciation recognized in some regions of Gondwana and the related mass extinction event are recorded within the interval proposed here as the Hirnantian Stage. Many authors have employed the "Hirnantian Stage" as an informal unit for the uppermost Ordovician interval, defined by the occurrence of the Hirnantia Fauna (Rong and Harper, 1988; Underwood et al., 1998; Fortey et al., 2000; Brenchley et al., 2003). Brenchley (1998) proposed a basal Hirnantian boundary candidate in the Oslo region based on the occurrence of the Hirnantia fauna-bearing beds and promising results from carbon isotopic analysis. However, data from South China suggest that the first and last appearances of the Hirnantia Fauna are diachronous (Rong, 1979; Rong and Harper, 1988; Rong et al., 2002). Rare core elements of the Hirnantia Fauna occur as low as at the top P. pacificus Biozone. The majority of the Hirnantia Fauna occurs within the N. extraordinarius Biozone and disappears in the $N$. persculptus Biozone. However, individual elements of the fauna extend as high as basal Silurian (lower P. acuminatus Biozone) in a few sites, marking the latest representatives of the Hirnantia Fauna (Harper and Williams, 2002; Rong et al., 2002). 
Thus, a graptolite biozone, in particular the base of the N. extraordinarius Biozone, which has shown no evidence of significant diachroneity, is a more appropriate criterion by which to define the base of the Hirnantian Stage.

Koren' and Nikitin (1982) suggested that the N. extraordinarius and $N$. persculptus biozones be equivalent to the Hirnantian Stage. Their concept was accepted by Brenchley $(1984,1989)$ and followed by many others. Fortey et al. $(1995,2000)$ correlate the base of the British Hirnantian Stage to a level slightly below the base of the N. extraordinarius Biozone, within the Paraorthograptus pacificus Subzone of the Dicellograptus anceps graptolite biozone. In adopting the Hirnantian Stage as the third or uppermost stage of the Upper Ordovician Series, the voting members of the Ordovician Subcommission considered that the base of the stage was best defined in a stratotype section at a level corresponding to the FAD of N. extraordinarius.

In 1999 at the 8th International Symposium on the Ordovician System, when the Subcommission was considering a two-fold subdivision of the Upper Ordovician Series, Rong et al. (1999) proposed the Hirnantian as a global substage. In China, the lower zone of their Hirnantian Substage was the N. extraordinarius $-N$. ojsuensis Biozone (Rong et al., 1999, Chen et al., 2000), the base of which coincided with the FADs of both the N. extraordinarius and N. ojsuensis. Subsequent, high-resolution resampling of the Wangjiawan North section has shown that the FADs of these two species are not at the same level as suspected previously. $N$. ojsuensis first occurs $4 \mathrm{~cm}$ below $N$. extraordinarius as is the case in many other parts of the world. Thus, the name of the lower biozone is revised to the N. extraordinarius Biozone. The top of the Hirnantian Stage is the base of the Silurian System. Accordingly, the Hirnantian Stage consists of two zones: the N. extraordinarius Biozone (lower) and N. persculptus Biozone (upper). These two biozones are known from many sections in the Yichang region where they occur in association with their underlying and overlying biozones.

\section{The Wangjiawan North section}

Wangjiawan is a small village, $42 \mathrm{~km}$ north of Yichang city and the Wangjiawan North section is located at $30^{\circ} 58^{\prime} 56^{\prime} \mathrm{N}, 111^{\circ} 25^{\prime}$ 10 ''E. It occurs on the east flank of the Huangling Anticline, which has a core of Precambrian rocks (Figure 2). The Ordovician-Silurian transitional strata in this area are well developed and outcropped at Huanghuachang, Fenxiang, through Wangjiawan, to the neighbouring counties northwards. The strata across the Ordovician-Silurian boundary at Wangjiawan include the Wufeng Formation, Kuanyinchiao Bed, and Lungmachi Formation in ascending order. The biozonation through these lithostratigraphic units was defined by $\mathrm{Mu}$ et al. (1984), Wang et al. (1987) and Mu et al. (1993), and revised by Chen et al. (2000) and the present paper (Figure 3).

The Wangjiawan exposure extends over approximately $150 \mathrm{~m}$ along strike (Figure 4), and both ends (Wangjiawan North and Wangjiawan South) have been intensively collected and correlated (Mu and Lin, 1984; Wang et al., 1987; Rong et al., 1999; Chen et al., 2000, 2003; and Chen and Rong, 2002; with an additional collection very recently). Hirnantian graptolites from Wangjiawan have been described by Wang et al. (1983), Mu and Lin (1984), Chen and Lin (1984), Lin and Chen (1984), as well as Chen et al. (2005a) recently. Approximately $80 \mathrm{~m}$ southeast of the Wangjiawan South section (about $270 \mathrm{~m}$ away from the Wangjiawan North section) is the Wangjiawan riverside exposure, where the OrdovicianSilurian transition is composed of less weathered rocks and possesses good potential for chemostratigraphical study. However, both the Wangjiawan North and South sections are intensively weathered to a dark brown colour, making graptolites more clearly visible on the bedding surfaces. The Wufeng Formation and the Lungmachi Formation at Wangji-

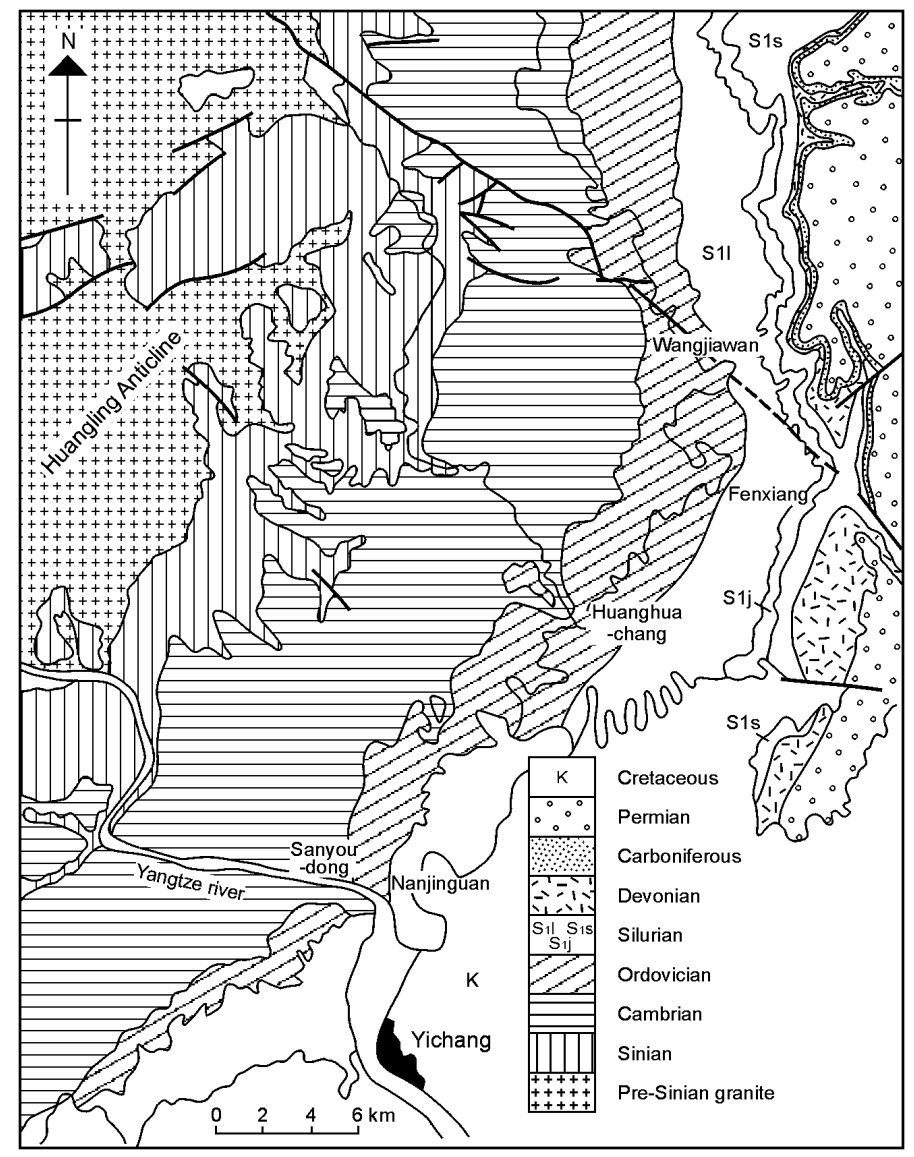

Figure 2 A geological map from the Yichang area, Western Hubei, China (Modified from Wang et al., 1987). The Hirnantian strata distributed along the top of the Ordovician in the Yichang area.

awan are all characterized by black shale, siliceous shale (weathered to a dark brown colour), and cherts, and the Kuanyinchiao Bed by argillaceous limestone. The boundary between the $N$. extraordinarius Biozone and its underlying beds shows no evidence of a lithological discontinuity or break in sedimentation (Figure 5). The stratigraphical column and faunal range chart in the present proposal is based on Chen et al. (2000, Figure 4) with new additional data and the systematic revisions of Chen et al. (2005a) (Figure 6). The base of the $N$. extraordinarius Biozone strata and its underlying beds are described as follows in descending order.

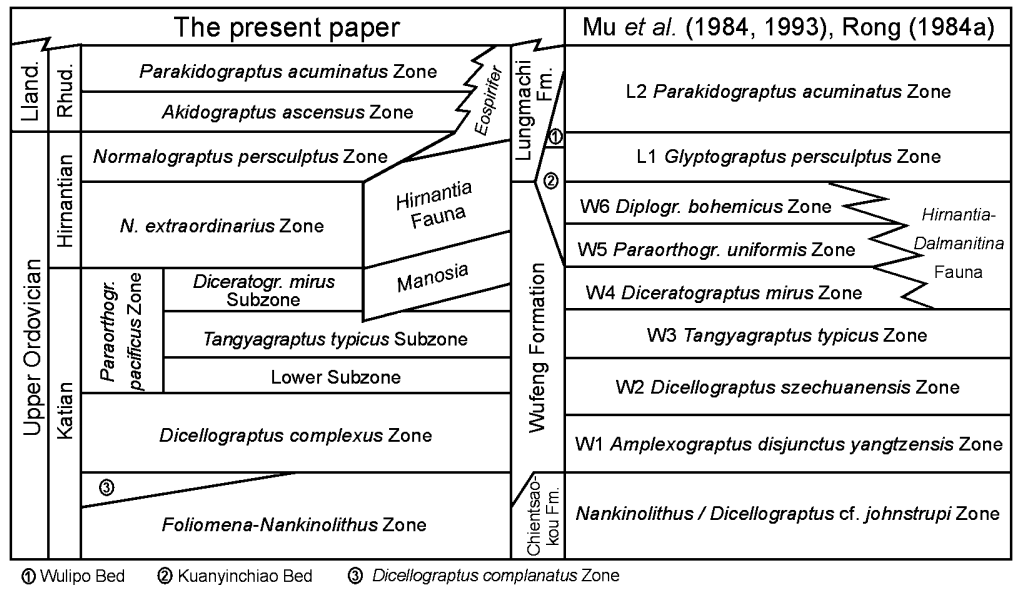

Figure 3 Late Ordovician to earliest Llandovery biozonation of South China (modified from Chen et al., 2000). 


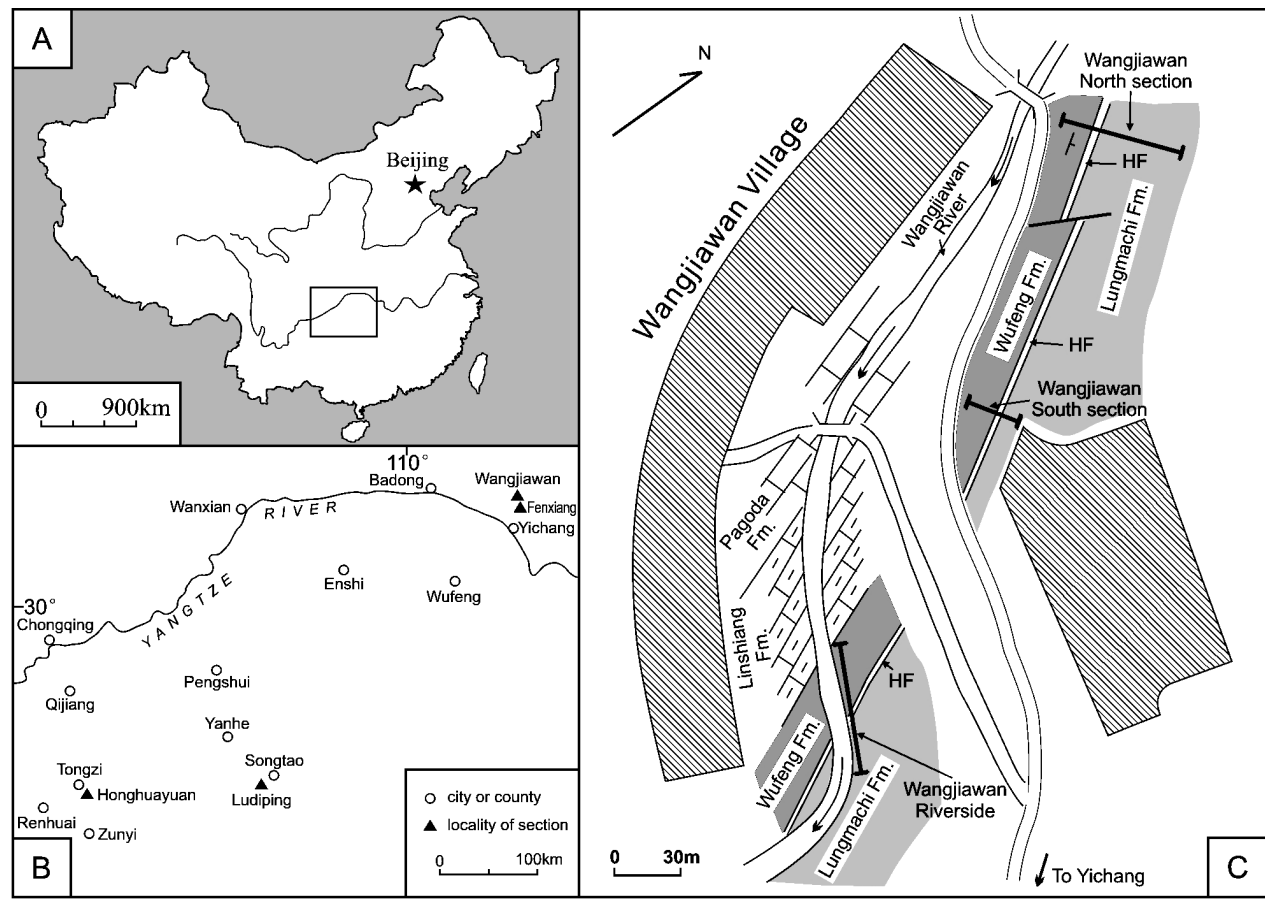

Figure 4 A simplified geological map of Wangjiawan, Yichang, China.
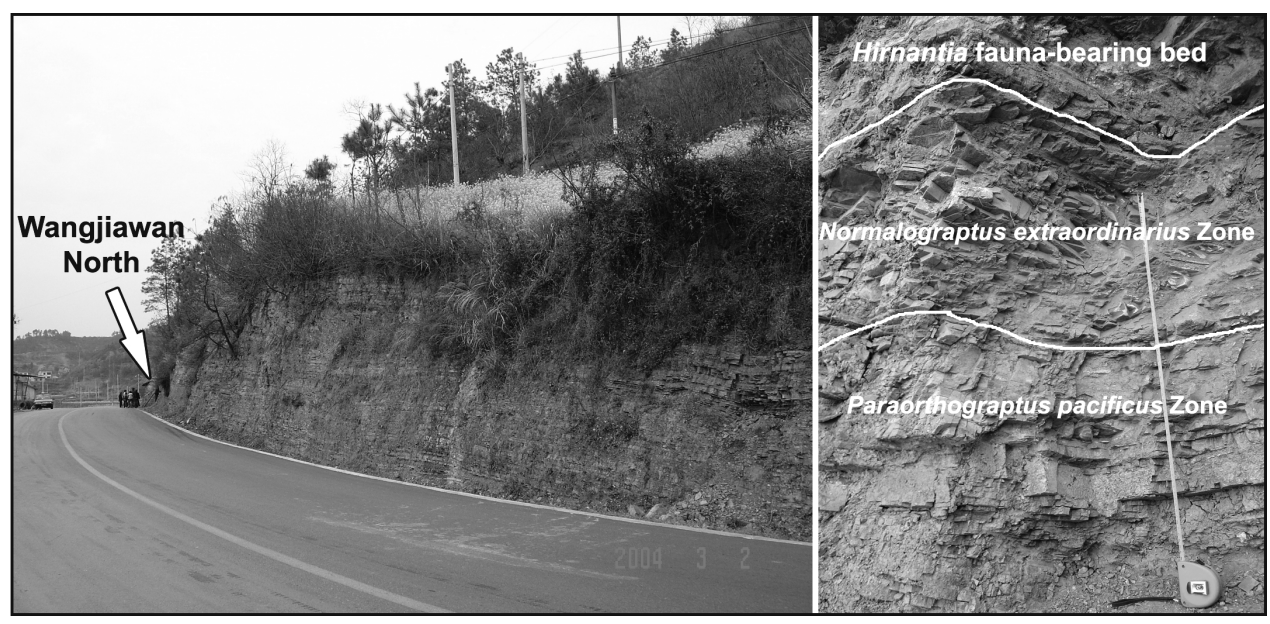

Figure 5 Photos showing the continuous lithological change between the base of the Hirnantian Stage and its underlying beds and the extension of the Ordovician-Silurian transitional rocks. The tape is $\mathrm{c} .70 \mathrm{~cm}$ long.

\section{Wufeng Formation}

Lower part of the N. extraordinarius Biozone

AFA 97b $(6.5 \mathrm{~cm})$. Dark brown siliceous shale, yielding $N$. ojsuensis (=formerly $N$. bohemicus by many Chinese graptolite specialists, Chen et al., 2005a), etc.

AFA 97a $(7.0 \mathrm{~cm})$. Dark brown siliceous shale, yielding N. extraordinarius, $N$. ex. gr. extraordinarius, $N$. ojsuensis and others.

Diceratograptus mirus Subzone of the P. pacificus Biozone AFA 96b $(4.0 \mathrm{~cm})$. Dark brown siliceous shale, yielding $N$. ojsuensis and Diceratograptus mirus and others.

AFA $96 \mathrm{a}(4.0 \mathrm{~cm})$. Dark brown siliceous shale, yielding D. mirus and others.

AFA 95b $(6.5 \mathrm{~cm})$. Black siliceous shale and cherts, yielding a slightly lower diversity graptolite fauna, similar to that of the underlying and overlying faunas.

AFA 95a $(5.0 \mathrm{~cm})$. Black siliceous shale weathering into dark brown with a high diversity Dicranograptidae-DiplograptidaeOrthograptidae fauna (DDO fauna, Melchin and Mitchell, 1991).
A species Normalograptus sp., which is related to $N$. ojsuensis, occurs in this bed.

At the Wangjiawan North section the FAD of $N$. ojsuensis occurs at AFA $96 \mathrm{~b}, 4 \mathrm{~cm}$ below the FAD of $N$. extraordinarius. Thus, the successive occurrences of $N$. ojsuensis and $N$. extraordinarius agree well with those observed in Nevada (Finney et al., 1999), Mirny Creek, Kolyma (Koren' et al., 1983, 1988), and Southern Kazakhstan (Koren' in Apollonov et al., 1980). These two relatively large species share many characters of thecal form and proximal development not seen in other pre-Hirnantian normalograptid taxa. We can therefore support the suggestion made by Koren' et al. (1983) that, among the taxa known from this interval, $N$. ojsuensis is the species most likely to be ancestral to $N$. extraordinarius. In addition, Normalograptus sp., which occurs $10-15 \mathrm{~cm}$ below the FAD of $N$. ojsuensis, is similar and possibly ancestral to $N$. ojsuensis, differing only slightly in the size of the rhabdosome and shape of the distal thecae (Chen et al., 2005a). With the lower boundary of the Hirnantian Stage defined at the base of bed AFA 97a in the Wangjiawan North section, it can be correlated with great precision into sections in Nevada, Kolyma, and Kazakhstan based on the consistent first appearance of $N$. extraordinarius relative to that of $N$. ojsuensis. In these sections, the first appearance of $N$. ojsuensis occurs consistently at the top of the Paraorthograptus pacificus Biozone with its highly diverse DDO fauna and at the base of the $N$. extraordinarius Biozone, which is dominated by a low diversity fauna of normalograptids and in which most species of the DDO fauna are lacking, having suffered mass extinction. Thus, even in graptolite bearing sections worldwide where $N$. ojsuensis or $N$. extraordinarius or both are missing, the stratigraphic level of the base of the Hirnantian Stage still can be located with considerable precision. It is for these reasons that the FAD of $N$. extraordinarius is a most reliable biohorizon on which to mark the boundary in the stratotype section.

The Wangjiawan North section possesses the following advantages for the Hirnantian Stage GSSP.

1. Continuity of sedimentation and biozonation. The section shows continuous sedimentation and a complete biozonation through the boundary interval, the Hirnantian Stage, and the Ordovician-Silurian transition. Although the section is condensed, the graptolite succession in the boundary interval is exceptionally well developed. The latest Ordovician mass extinction occurred into two phases with the first phase being the near annihilation of graptolites at the base of the $N$. extraordinarius Biozone worldwide, except in the Yangtze Region of China. The Yangtze Region appears to have served as a graptolite refugium (Mitchell et al., 2003). Although extinction rates as recorded in the Chinese sections were high, many taxa of the pre-extinction DDO fauna extend into the Hirnantian Stage (Chen et al., 2005b). Elsewhere in the world, their extinctions are earlier and appear to be diachronous between shallow and deepwater stratigraphic successions, reflecting facies control (Brenchley, 


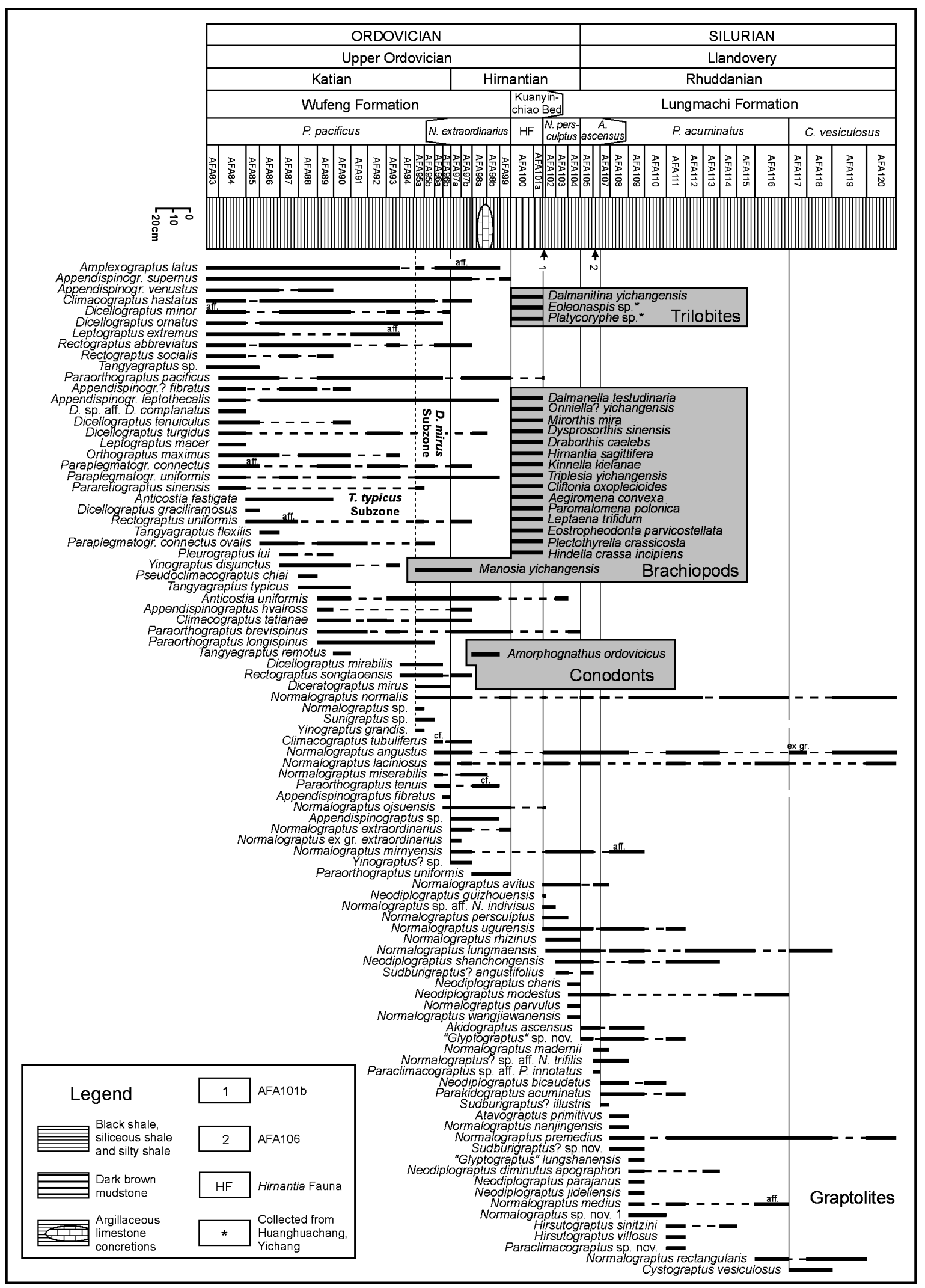

Figure 6 Stratigraphic column through the Ordovician-Silurian transition with ranges of graptolites and shelly faunas from the Wangjiawan North section.

1984; Harper and Rong, 1995; Sheehan, 2001). Thus, the Wangjiawan North section with the most complete and continuous graptolite succession through the boundary interval in the Yangtze Region is considered to be the best succession to define a boundary based on the graptolite fauna (Chen et al., 2005b). There the faunal turnover is evidently less affected by contemporaneous environmental changes than is the case elsewhere in the world.

2. Completeness of exposures. The Wangjiawan North section is in a clean outcrop that extends more than $150 \mathrm{~m}$ along strike, and it is close to many other sections spanning the boundary interval 
(approximately 40 sections studied in the Yangtze Region and ten in the vicinity of Yichang).

3. Abundant and well-preserved graptolites and shelly fossils. The graptolite succession at Wangjiawan North is outstanding. A thin interval of argillaceous limestone (the Kuanyinchiao Bed) with the Hirnantia Fauna occurs between the N. extraordinarius and $N$. persculptus biozones at Wangjiawan North. This shelly fauna includes trilobites, nautiloids, and various microfossils (Rong, 1979, 1984b; Zhu and Wu, 1984; Wang et al., 1983, 1987; Chen et al., 2000). Conodonts are very rare because of the absence of clean carbonates in the Ordovician and Silurian boundary strata in the Yangtze Region. Wang et al. (1987) listed Amorphognathus ordovicicus and other forms from the Wufeng Formation and Chen et al. (2000) further confirmed the existence of A. ordovicicus, identified by S. M. Bergström and Wang Zhi-hao, from a limestone lens of the N. extraordinarius Biozone at Wangjiawan (Figure 5).

4. Favorable facies and widespread correlation potential. As discussed above, the FAD of $N$. extraordinarius is a biohorizon that occurs at a level in the graptolite succession that provides for reliable, precise worldwide correlation. It occurs at a stratigraphic level where there are other stratigraphic markers that allow for correlation into most Upper Ordovician sections worldwide.

5. Free from structural complication. There are no faults, folds, or other tectonic complications at the selected Wangjiawan North section.

6. Free from metamorphism or other thermal alteration. The strata have not experienced a high degree of metamorphism and thermal alteration. The study of organic-walled fossil reflectance and IRspectroscopy indicate that the vitrinite reflectance equivalent of the Wangjiawan section is estimated to be $1.3 \% \mathrm{R}$ (Wang et al., 1993). We are currently working on palynomorphs, acritarchs, chitinozoans and chemostratigraphy from the Wangiiawan North, South, and Riverside sections. Organic carbon preservation in the section is adequate to produce a reliable $\delta^{13} \mathrm{C}_{\text {org }}$ record through the latest Ordovician and earliest Silurian. The previously published (Wang Kun et al., 1993) and newly collected data (see discussion below) exhibit a positive excursion in the Hirnantian comparable to that present in this interval at other sections around the world and demonstrate that the Hirnantian strata at Wangjiawan are suitable for chemostratigraphic correlation studies.

7. Amenability to isotopic age determination. Some bentonites in the Ordovician and Silurian boundary strata offer a potential for determining radiometric dates. Ross and Naeser (1984) published early results based on a sample from the Wufeng Formation of Yichang.

8. Accessibility. The Wangjiawan section is present on the side of a well-paved country highway, about one hour's drive from the Yichang city. Daily local bus service between Yichang and Wangjiawan is available. The transportation between Yichang and the big cities of China is available by airline, railway, buses, and ships along the Yangtze River.

9. Presence of possible ancestor of the key index taxa for this interval. As noted above, evidence from this section suggests that $N$. extraordinarius may be derived from a lineage including $N$. sp. and N. ojsuensis.

When the decision was made by the Ordovician Subcommission to establish the Hirnantian Stage as the highest stage in the Ordovician System, the Wangjiawan North section was the only section to be proposed as a stratotype. This reflected the facts that the section had already been proposed as a stratotype for the base of the Hirnantian Substage (Rong et al., 1999), that it was thoroughly studied and documented, and that it was favored by many. It has an outstanding graptolite succession through the boundary interval (Chen et al., 2005b) and it includes the Hirnantia Fauna (Rong, 1984b). The only other potential candidates are the Vinini Creek section in Nevada and the Mirny Creek section in Kolyma. Although the Vinini Creek section has many attributes (graptolite, conodont, and chitinozoan successions in the boundary interval, distinct stratigraphic record of sea-level fall), the FAD of $N$. extraordinarius falls within an interval of intense extinction and corresponds closely with a vertical change in facies. Thus, although the graptolite record at Vinini Creek is continuous and diverse, it does not compare to the quality of that at Wanjiawan North where the extinction is much less intense, there is no marked facies change, and graptolite diversity is much greater. Also, the Vinini Creek section has no record of the Hirnantia Fauna. The Mirny Creek section has an excellent graptolite succession in an expanded section with interbedded carbonate strata that could yield rich benthic faunas and conodonts. However, there is no typical Hirnantia Fauna recorded (Rong and Harper, 1988), and the limestone beds have failed to yield a definitive conodont fauna. In addition, access to the Mirny Creek section is very difficult and expensive.

\section{Regional Correlation of the Hirnantian Stage}

The Hirnantian Stage has been studied at as many as 43 sections in South China, with most of these being on the Yangtze Platform (Chen et al., 2000). There is substantial variation between relatively deep-water and relatively shallow-water sections, which is reflected in variation in diversity of graptolite species and in diversity and stratigraphic extent of the Hirnantia Fauna (Rong et al., 2002). In many of the sections, calacareous mudstone beds bearing the Hirnantia Fauna occupy a substantial stratigraphic interval from which graptolites are absent. At its greatest, this interval begins low in the $N$. extraordinarius Biozone and extends as high as the lowest Silurian $P$. acuminatus Zone, although typically it occupies the upper part of the N. extraordinarius Biozone and the lowest $N$. persculptus Biozone. In spite of this variation, the base of the Hirnantian Stage can be precisely correlated in to all of the South China sections on the basis of the graptolite succession in the boundary interval, in particular on the consistent level of the first appearance of $N$. extraordinarius within the graptolite succession. The Honghuayuan section is a typical shallow-water section (Chen et al., 2000; Figure 7). The $N$. extraordinarius Biozone (AFA 290-302) at Honghuayuan is $4.25 \mathrm{~m}$ thick and the $N$. persculptus Biozone (AFA 303-308) is $1.71 \mathrm{~m}$. The $N$. extraordinarius Biozone is characterized by a remarkably low diversity graptolite fauna, mainly $N$. extraordinarius and $N$. ojsuensis, and is underlain by the Diceratograptus mirus Subzone of the $P$. pacificus Biozone (Chen et al., 2000). The base of the Hirnantian Stage at Honghuayuan is coeval with that at Wangjiawan North. The Kuanyinchiao Bed with a shelly fauna at Honghuayuan covers an interval from the middle $N$. extraordinarius Biozone to middle $P$. acuminatus Biozone with no graptolites in the shelly sequence (Rong et al., 2002). A typical Hirnantia Fauna occurs in the lower part of the Kuanyinchiao Bed (AFA 295-307) in which Hirnantia sagittifera and other species characteristic of the fauna are present (Chen et al., 2000; Rong et al., 2002), but again species diversity at this section is relatively low compared to that at Wangjiawan, as pointed out by Rong and Harper (1988).

\section{Global Correlation of the Hirnantian Stage}

Chen et al. (2000) presented a detailed description of the issues surrounding the global correlation of the base of the Hirnantian Stage. These correlations were based largely on graptolite biostratigraphy and the stratigraphic range of the Hirnantia Fauna, and they are summarized below (Figure 8). The critical issue is the identification of the point in time represented by the GSSP, which we suggest be set by the first appearance of $N$. extraordinarius in the Wangjiawan North section. This event appears to be a little later than that of the first appearance of $N$. ojsuensis and to substantially precede the major graptolite extinction of the diverse dicranograptid, diplograp- 


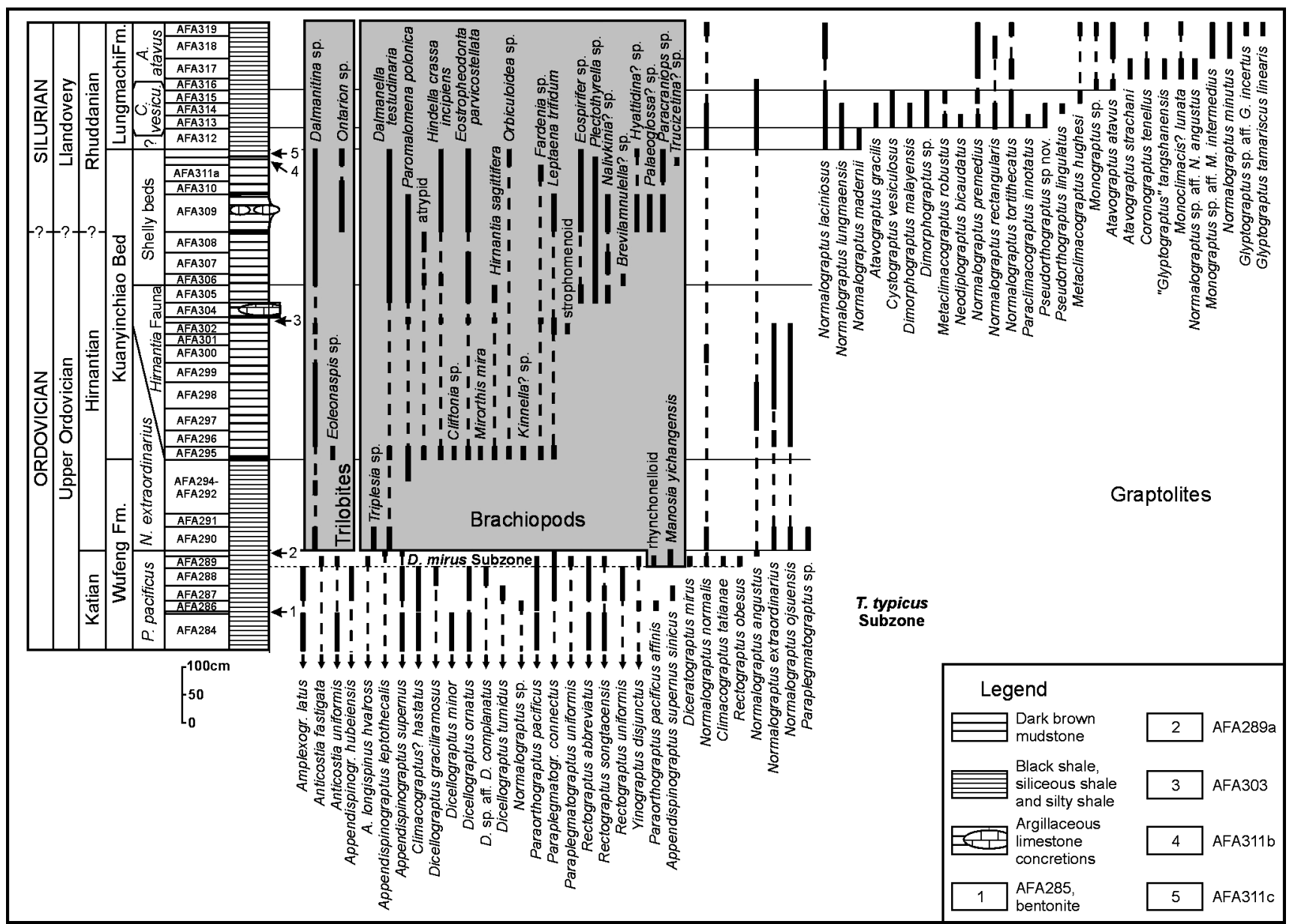

Figure 7 Stratigraphic column through the Ordovician-Silurian transition with ranges of the graptolites and shelly faunas from the Honghuayuan section. Modified from Chen et al. (2000).

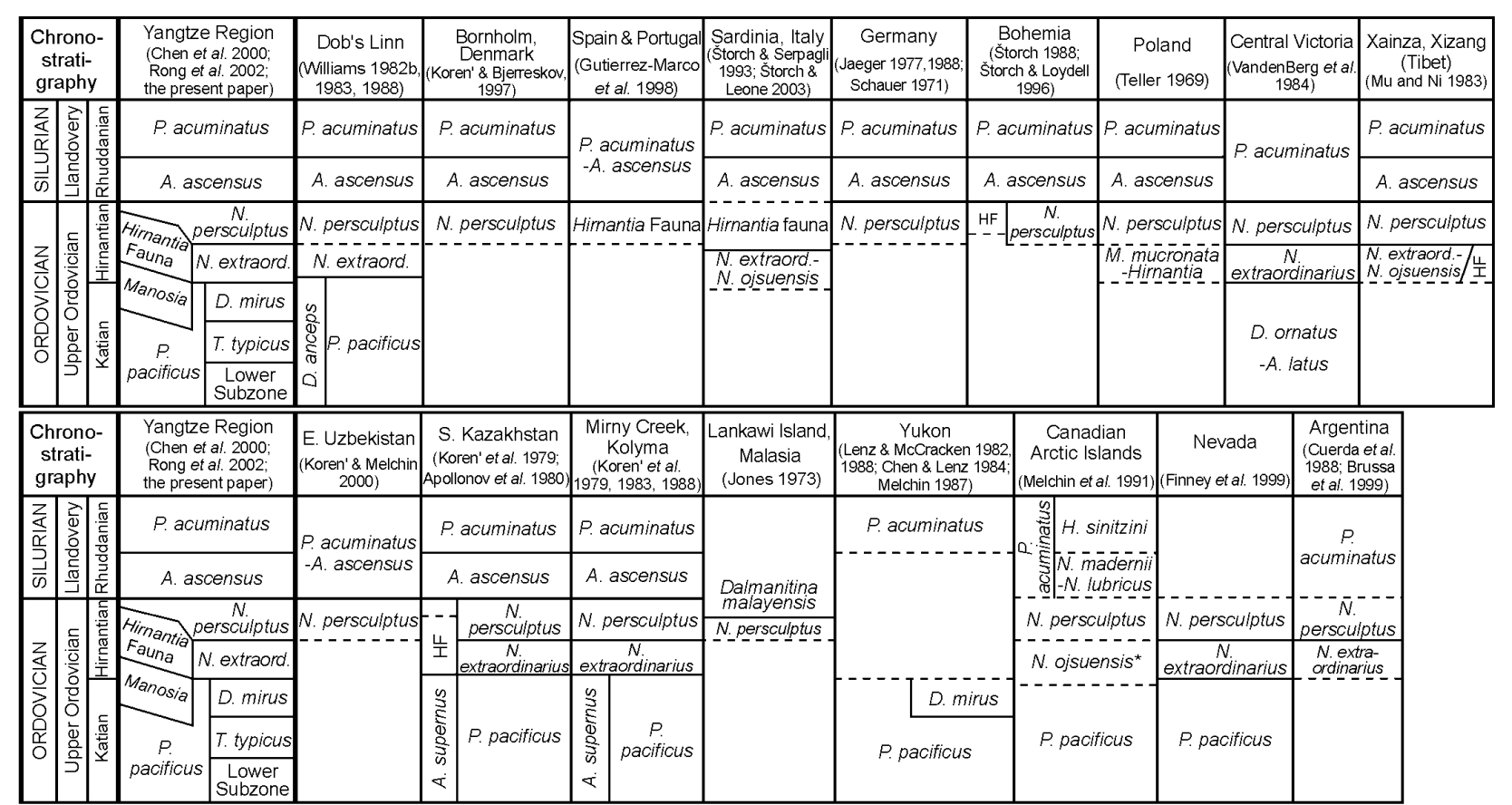

Figure 8 A global correlation of the Hirnantian Stage and its underlying and overlying strata.

tid, and orthograptid species (the "DDO fauna") in deeper water facies. From the description of the FAD of $N$. extraordinarius and its relation with $N$. ojsuensis, we may easily correlate the base of the Hirnantian Stage at Wangjiawan North with that of Nevada (Finney et al., 1999), Mirny Creek, Kolyma (Koren' et al., 1983, 1988), and S. Kazakhstan (Koren' et al., 1979; Apollonov et al., 1980) as well as other locations around the world. 
At Dob's Linn, Scotland, two Hirnantian graptolite assemblages have been documented in intervals separated by unfossiliferous strata (Williams, 1988). As a result, the zonal boundaries, in particular the base of the Hirnantian Stage, are difficult to define precisely. $N$. extraordinarius occurs at two levels, the lower of which (Band E) was assigned by Williams (1988) to the upper part of the Dicellograptus anceps Zone because of its co-occurrence with a relatively diverse DDO fauna. However, we now know this to be a common association for the earliest Hirnantian strata, and thus, we assign the Band E occurrence to the lower part of the N. extraordinarius Biozone and the lower Hirnantian Stage. No Hirnantia shelly fauna (only Songxites) has been reported from Dob's Linn.

Koren' et al. (1983) described the Ordovician and Silurian graptolites from the Mirny Creek section, Kolyma. The N. extraordinarius Biozone there is marked by the FAD of $N$. extraordinarius, which is just above the FAD of $N$. ojsuensis. The FAD of $N$. ex gr. extraordinarius (Sobolevskaya, 1979) occurs together with that of N. extraordinarius there, as is the case at Wangjiawan North (AFA 97a). Thus, the occurrence of these two species agrees between these regions. The FAD of $N$. ojsuensis at Mirny Creek may also indicate an equivalent level of the upper D. mirus Subzone in the Yangtze Region. A Hirnantian brachiopod fauna, different from the typical Hirnantia Fauna, occurs mainly from the N. persculptus Biozone at Mirny Creek (Rong and Harper, 1988). Unfortunately, the level of the first occurrence of $N$. extraordinarius at this section is marked by the complete disappearance of all DDO taxa and the beginning of a very low diversity graptolite fauna (Koren' et al., 1983). In addition, the remote location of Mirny Creek makes access to the section difficult and expensive for resampling.

The Hirnantian Stage is well developed in Southern Kazakhstan. Both the N. extraordinarius Biozone (lower) and N. persculptus Biozone (upper) are present (Apollonov et al., 1980). The Hirnantia- Dalmanitina shelly fauna occurs with the N. extraordinarius graptolite fauna. The $A$. ascensus and $P$. acuminatus biozones occur above the $N$. persculptus Biozone. Normalograptus ojsuensis occurs below the $N$. extraordinarius biozone in the upper P. pacificus Biozone there. Thus, both the graptolite and the shelly faunal successions agree with those of the Wangjiawan North as well as with other sections in the Yangtze Region. However, the diversity of the graptolite fauna in Southern Kazakhstan appears to be lower than that of the shelly fauna, and, as at Mirny Creek, the FAD of N. extraordinarius occurs within a very low-diversity graptolite fauna.

Normalograptus ojsuensis is present in Arctic Canada within an interval referred to the $N$. bohemicus $(=N$. ojsuensis) Biozone by Melchin et al. (1991). This interval evidently lacks $N$. extraordinarius and immediately follows the complete disappearance of the DDO species. Therefore, it is not possible to precisely define the base of the Hirnantian Stage in Arctic Canada, although it most likely occurs near the level of the first appearance of N. ojsuensis. The upper Hirnantian in Arctic Canada can be recognized by the occurrence of the N. persculptus Biozone (Melchin et al., 1991).

Finney et al. (1999) reported that the FAD of N. ojsuensis occurs just below the FAD of $N$. extraordinarius at the top of the $P$. pacificus Biozone in the Vinini Creek section. The top of the P. pacificus Biozone at Vinini Creek may correspond to that of D. mirus Subzone at Wangjiawan North, indicating that the base of the Hirnantian Stage at Vinini Creek agrees with that of the Wangjiawan North section based on the $N$. ojsuensis $-N$. extraordinarius sequence. The diversity of the $N$. extraordinarius Biozone fauna at Vinini Creek is lower than that of Wangjiawan North. At Vinini Creek, graptolite diversity of the $N$. extraordinarius Biozone decreases substantially to seven species and then three species at the top (Finney et al., 1999) while at Wangjiawan North it decreases substantially from 24 species (AFA 97a) and then 10 species (AFA 99) just below the Kuanyinchiao Bed. Moreover, the typical Hirnantia shelly fauna is absent at Vinini Creek. The N. persculptus Biozone, typified by the appearance of the eponymous species, is present at both sections but again produces a much more diverse fauna at Wangjiawan North. In contrast to the condensed section at Wangjiawan North, the Vinini Creek section is expanded, and it is composed of a distinctive deep-water stratigraphic succession recording sea-level fall and lowstand and associated oceanographic changes (e.g. loss of anoxia) beginning in the top of the P. pacificus Zone and extending up to a level within the $N$. persculptus Zone. It also includes the Amorphoganthus ordovicicus conodont fauna, a diverse succession of chitinozoans, and a record of part of the positive carbon isotope succession. The Vinini Creek section, in turn, can be correlated on the bases of graptolite, conodont, and chitinozoan biostratigraphy into the nearby Copenhagen Canyon section, which is composed of a thick, outer-shelf carbonate succession (Finney et al., 1999). At this section, fossils disappear within the uppermost $N$. extraordinarius Zone, but the section includes the best documentation of the positive carbon isotope succession that can be precisely correlated into the sea-level fall, lowstand, and subsequent rise in a relatively shallow-water depositional environment.

Hirnantian graptolite assemblages have been recorded in Argentina from a number of different locations. Brussa et al. (1999) reported a moderately diverse, $N$. extraordinarius and DDO-bearing fauna from beds exposed near Calingasta, San Juan Province, near the western boundary of the Precordilleran Terrain, which appears to represent an early Hirnantian assemblage. The more proximal clastic sediments of the Don Braulio and Trapiche formations of the eastern Precordillera contain the shelly Hirnantia Fauna as well as glaciogenic sediments (Benedetto, 1986, 2003; Benedetto et al., 1999; Buggish and Astini, 1993; Astini, 2003). Cuerda et al. (1988) and Rickards et al. (1996) recorded a $N$. persculptus Biozone fauna below a P. acuminatus Biozone fauna at Talacasto near San Juan and at Cerro del Fuerte near Jáchal (respectively), in the central part of the Precordilleran Terrain. These graptolite-bearing, late Hirnantian strata succeed glaciogenic marine sediments at some sites but in other sections disconformably overlie much older rocks (Astini, 2003). These data suggest that the entire Hirnantian Stage as developed in the Yangtze Region may present in the San Juan Province, however, a biostratigraphically well-controlled, continuous succession through the Hirnantian Stage remains to be discovered in this region.

Additionally, at many localities from peri-Gondwanan regions, such as Spain and Portugal (Gutiérrez-Marco et al., 1998), Sardinia, Italy (Štorch and Serpagli, 1993), Thuringia, Germany (Jaeger, 1977, 1988; Schauer, 1971), Bohemia (Štorch, 1988; Storch and Loydell, 1996), and Poland (Teller, 1969), as well as Bornholm, Denmark of the Baltic region (Koren' and Bjerreskov, 1997), the N. extraordinarius Biozone is not well developed. This may indicate that the $N$. extraordinarius graptolite fauna occurred mainly in low to middle latitudes. However, Hirnantian graptolites and the Hirnantia Fauna are well developed in Xizang (Tibet) (Mu and Ni, 1983; Rong and $\mathrm{Xu}, 1987)$, a region that is generally considered to be part of periGondwana (Rong and Harper, 1988). The absence of the N. extraordinarius Biozone from East Uzbekistan (Koren' and Melchin, 2000), Yukon (Lenz and McCracken, 1982, 1988; Chen and Lenz, 1984), and Malaysia (Jones, 1973) might be caused by local facies controls or a local hiatus, or both. However, N. ojsuensis occurs in Bohemia (Štorch and Leone, 2003) and Niger (Legrand, 1988). This at least identifies a level that must be either just below or basal Hirnantian and suggests a basis for further work aimed at improving correlations into peri-Gondwana.

Since most of the core taxa of the Hirnantia Fauna appear first at the basal $N$. extraordinarius Biozone, with the exception of a few elements of the Hirnantia Fauna in the top P. pacificus Biozone in the Yangtze Region (Rong et al., 2002), the shelly fauna itself, as a whole, is considered Hirnantian age and documented as an indicator of the Hirnantian Stage in a shelly sequence without any records of graptolites. For a better understanding of the Hirnantian faunas from the Wangjiawan sections, the main elements of the graptolite and shelly faunas (brachiopods and trilobites) are shown in Figures 9 and 10. 


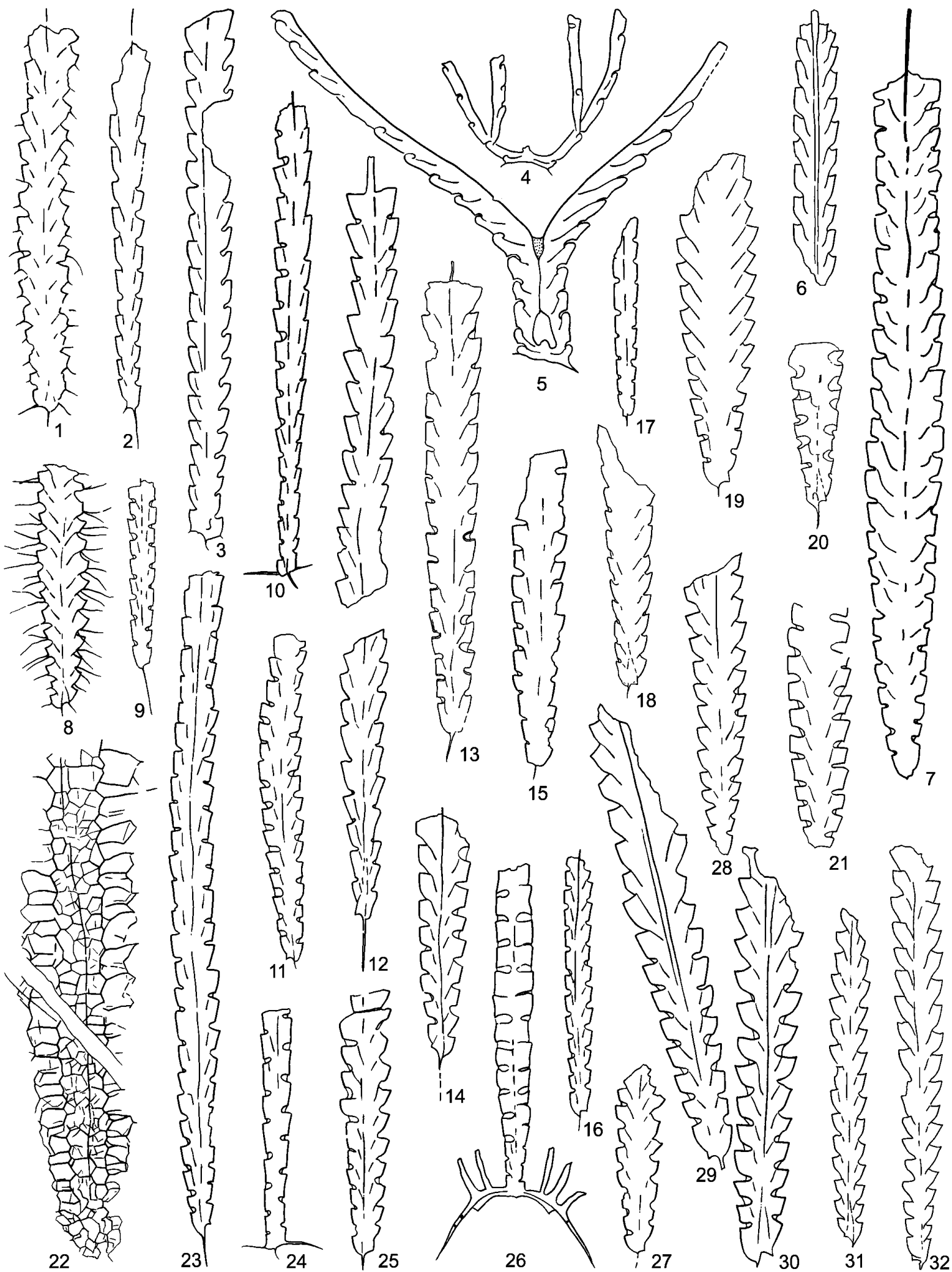

Figure 9 Main graptolites from the Wufeng and Lungmachi formations (Hirnantian Stage and its underlying strata) at Wangjiawan, Yichang. All figures are $\mathrm{X} 4$ with catalogue numbers (NIGP).

1. Paraorthograptus uniformis, NIGP 136732. 2. Normalograptus rhizinus, 136739. 3. Anticostia uniformis, 136733. 4. Tangyagraptus typicus, 136734. 5. Diceratograptus mirus, 136735. 6, 18. Normalograptus persculptus, 136753 and 133453. 7, 20, 21. Normalograptus extraordinarius, 136749, 133407 and 136737. 8. Paraorthograptus pacificus, 136740. 9. Climacograptus tatianae, 133370. 10. Appendispinograptus leptothecalis, 133381. 11. Normalograptus parvulus, 136751. 12, 23. Normalograptus avitus, 133344 and 136742. 13, 14, 15, 29, 30. Normalograptus ojsuensis, 133446, 136747, 136736, 136748 and 136748-1. 16. Normalograptus mirnyensis, 136746. 17. Normalograptus miserabilis, 136738. 19. Neodiplograptus modestus, 136731. 22. Paraplegmatograptus uniformis, 136741. 24. Appendispinograptus supernus, 136743. 25, 27. Normalograptus sp., 136745-1 and 136745. 26. Appendispinograptus venustus, 136750. 28. Neodiplograptus daedalus, 136754.31,32. Normalograptus laciniosus, 136752 and 133417. 

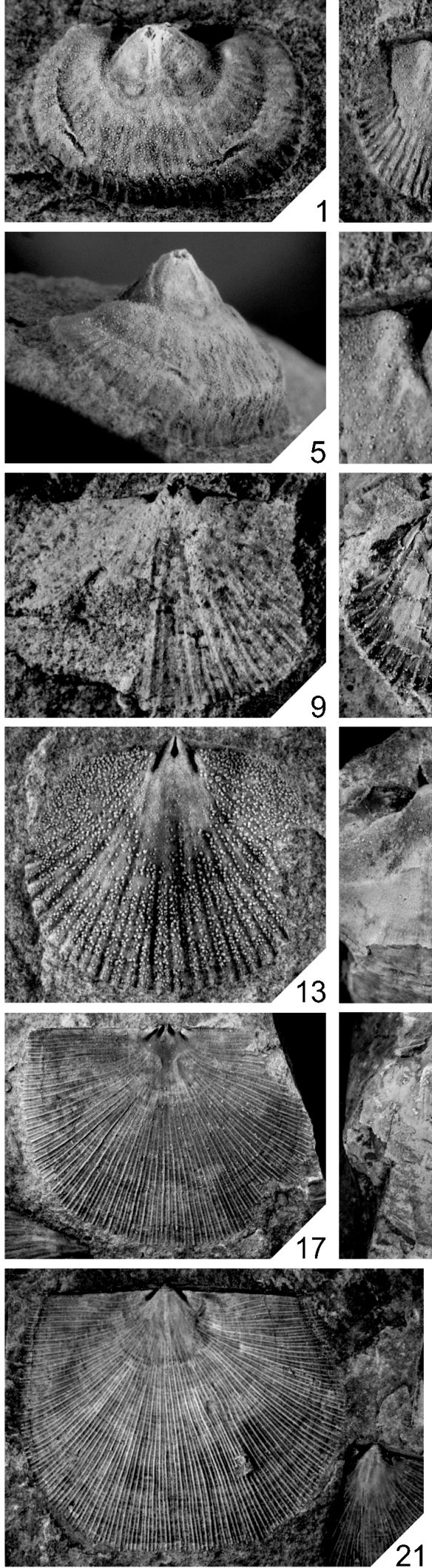
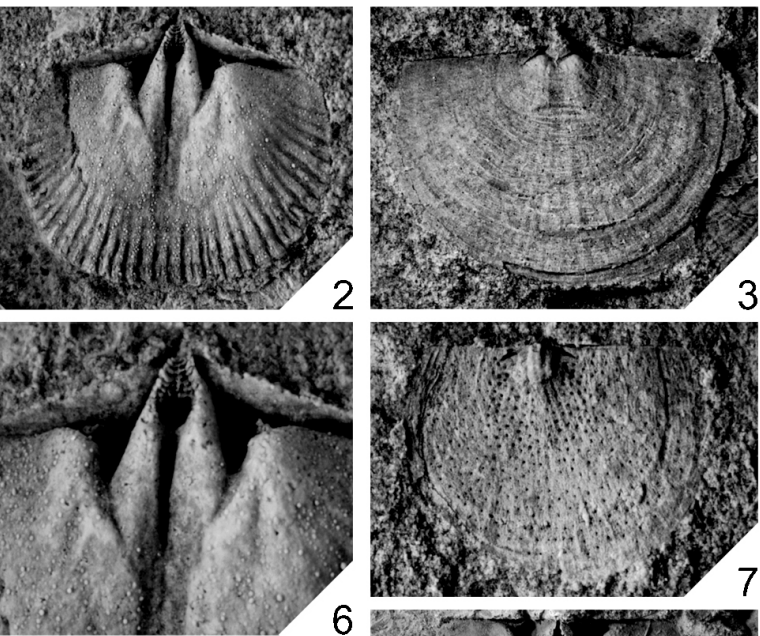

6
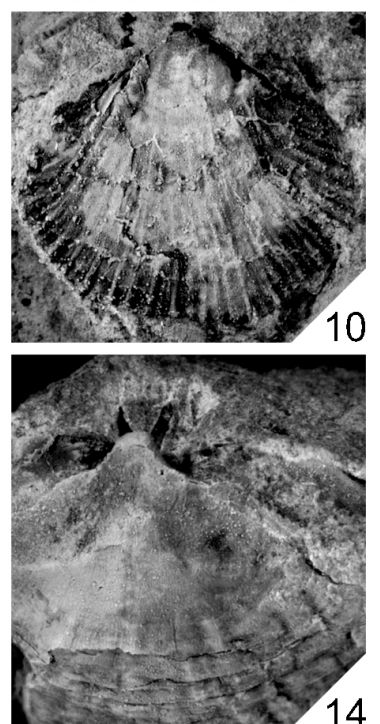

10
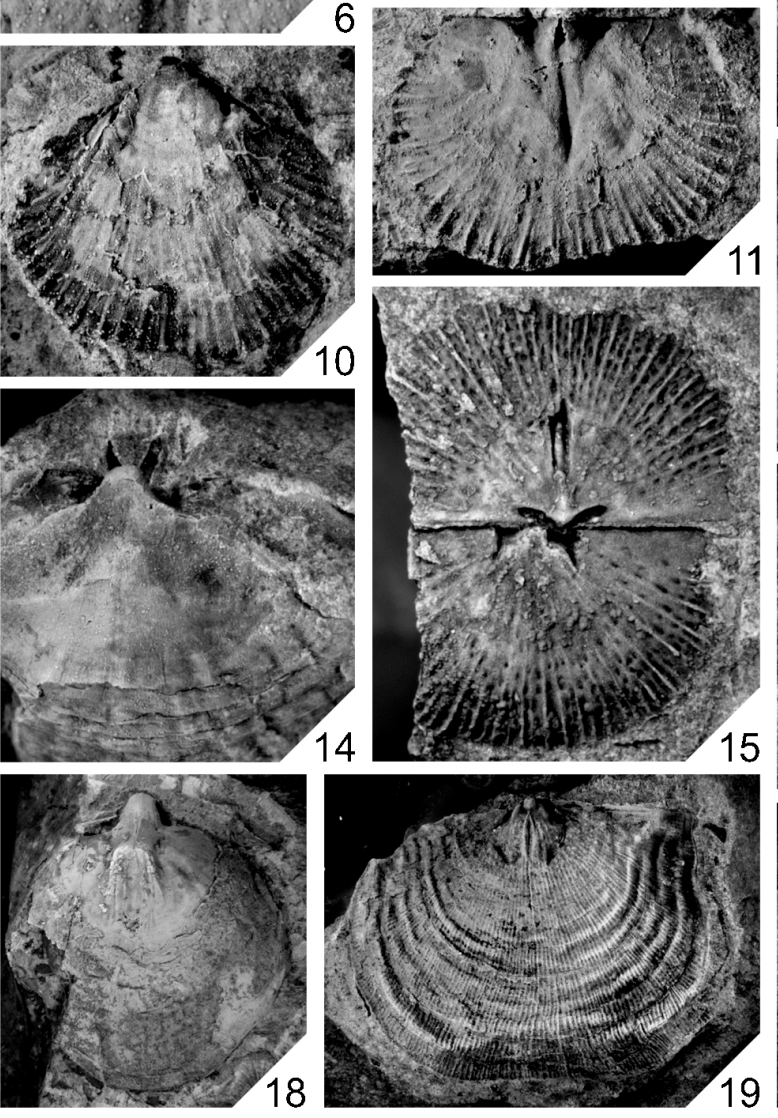

15
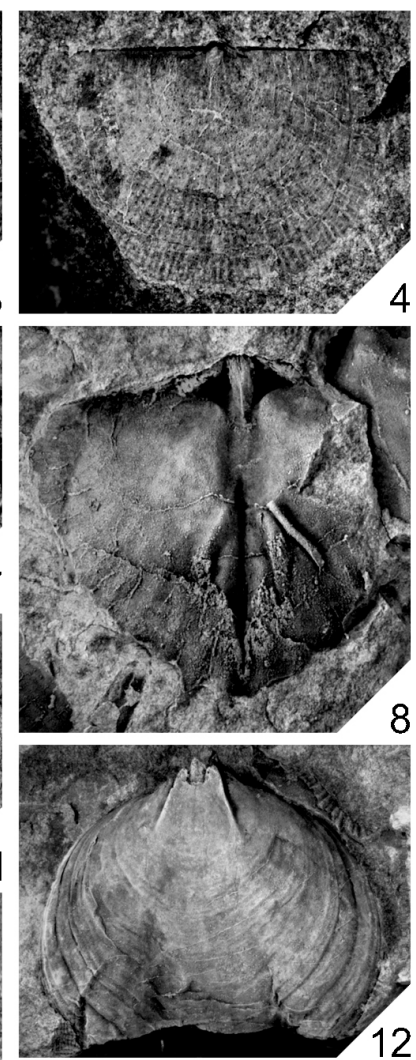

12
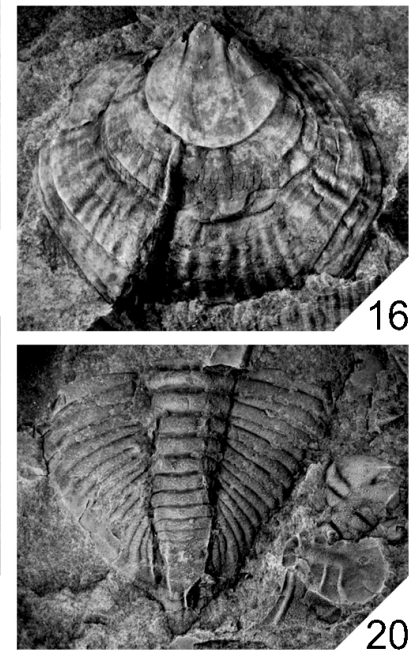

20
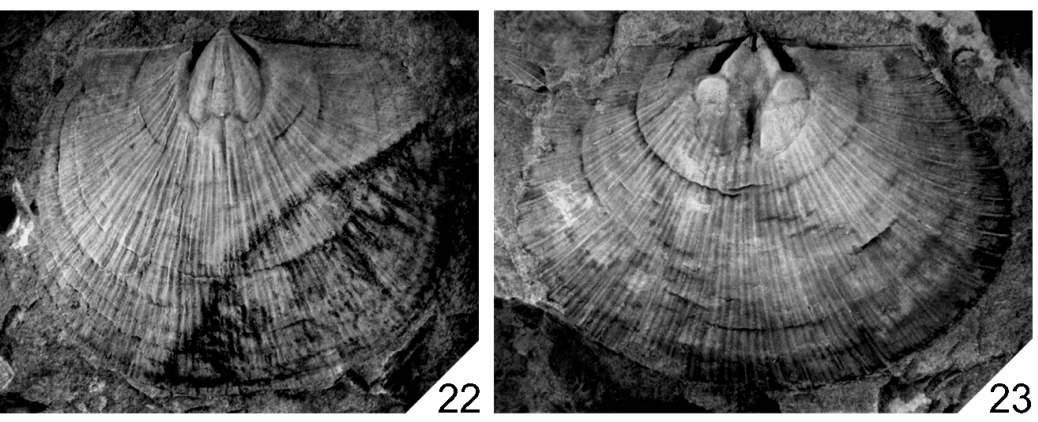

Figure 10 Brachiopoda and trilobite from the Kuanyinchiao Bed (Hirnantian Stage) at Wangjiawan.

1, 2, 5, 6. Kinnella kielanae, 1, 5, x 6.8, x 7.7 (NIGP136755); 2, 6, x 7.1 and x 12.8 (136756). 3, 4, 7. Paromalomena polonica, 3 , x 5.4 (136757); 4, 7, x 5.3, x 9.3 (136758-9). 8. Plectothyrella crassicosta, x 2.9 (136760). 9, 10. Dysprosorthis sinensis, x 7.1, x 4.2 (136761-2). 11. Draborthis caelebs, $x 3.6(136763)$. 12. Triplesia yichangensis, $x 2.7(136764)$. 13. Dalmanella testudinaria, $x 5.8(136765) .14,16$. Cliftonia oxoplecioides, $x$ 2.7, x 4.7 (136766-7). 15. Aegiromena ultima, $x 7.9$ (136768). 17, 21. Eostropheodonta parvicostellata, $x 4.4$, $x 1.8$ (136769-70). 18. Hindella crassa incipiens, $x$ 1.6 (136771). 19. Leptaena trifidum, $x 1.6(136772) .20$. Dalmanitina sp., x 3.7 (136773). 22, 23. Hirnantia sagittifera, x 1.7, x 2.1 (136774-5). 


\section{Carbon Isotope Analysis of the Wangjiawan Riverside Section}

Although the Wangjiawan North and the Wangjiawan South sections yield abundant and diverse graptolites and shelly faunas, they are not suitable for geochemical analysis since the rocks are intensively weathered. Fortunately, along the Wangjiawan riverside, c. $180 \mathrm{~m}$ southeast of the Wangjiawan North section (Figure 4), there occurs another section that spans the Ordovician and Silurian boundary in which the rocks are almost un-weathered and suitable for geochemical analysis. Thirty-four samples were continuously collected from the un-weathered graptolitic shales (the Wufeng Formation and Lungmachi Formation) and the argillaceous limestone (the Kuanyinchiao Bed) along the Wangjiawan Riverside by Fan Junxuan and Peng Ping'an in June of 2005. The sampled interval spans the mid$P$. pacificus Biozone to the $P$. acuminatus Biozone and covers the two graptolite extinction events (Chen et al., 2005b). The carbon isotope analysis of isolated kerogen was performed in the State Key Laboratory of Organic Geochemistry, Guangzhou, China by Peng Ping'an and his colleagues with the isotope ratio mass spectrometer (EA / Delta S Plus XL). Standard deviation of $\delta^{13} \mathrm{C}$ measurements is less than 0.1 per mill. The graptolites from the same levels were collected and identified by Fan and Chen sample-by-sample. The graptolite biozonation, thus, could be precisely correlated with those of the Wangjiawan North and Wangjiawan South sections.

There are two major peaks in the organic $\delta^{13} \mathrm{C}$ values at the Wangjiawan Riverside section, although the curve exhibits some fluctuation in values throughout (Figure 11). The $\delta^{13} \mathrm{C}$ becomes more positive from the base of the D. mirus Subzone and reaches its first peak at the mid-N. extraordinarius Biozone. It is followed by a slight decline in values in the upper N. extraordinarius Biozone. The first positive excursion of $\delta^{13} \mathrm{C}$ coincides well with the first and major extinction event of graptolites as demonstrated by Chen et al. (2005b). After that, the $\delta^{13} \mathrm{C}$ rises again and reaches its highest value at the middle of the Kuanyinchiao Bed and then drops dramatically

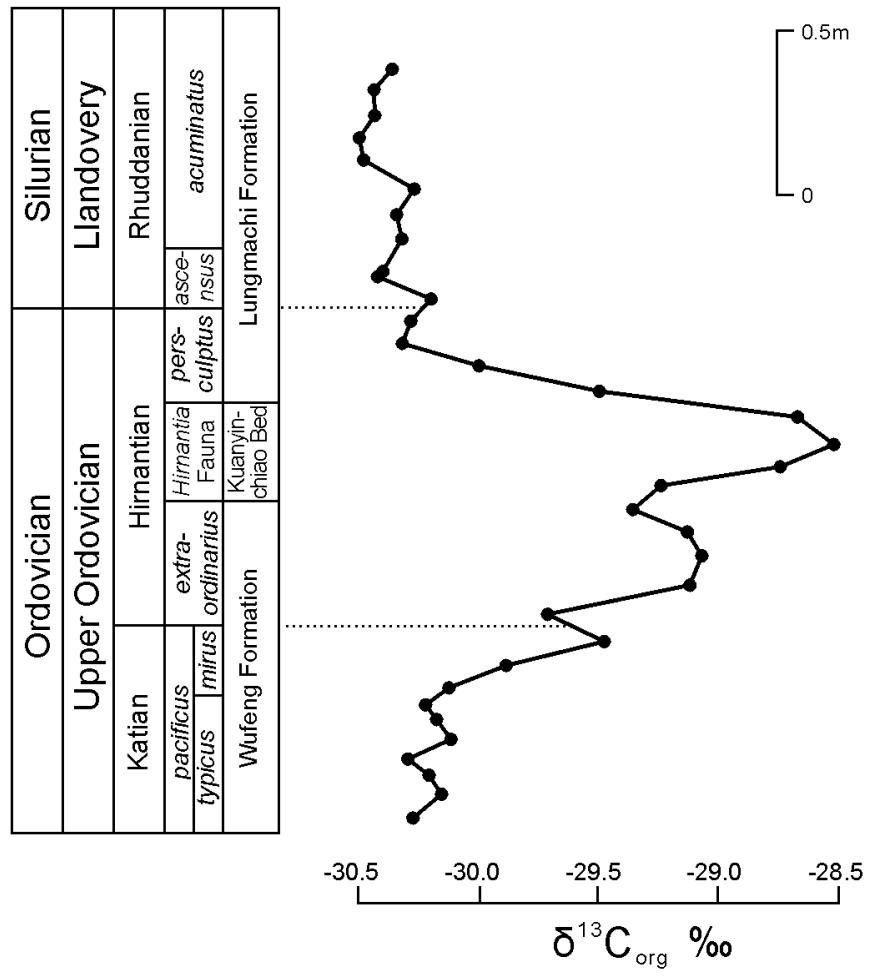

Figure 11 Organic carbon isotopic curve of isolated kerogen at the Wangjiawan Riverside section with time scale for uppermost Ordovician showing Systems, Series, Stages, biozonations and lithostratigraphic units. from $-28.5 \%$ to $-30.3 \%$. Graphic correlation of Late Ordovician sections throughout South China suggests that regionally, the base of the $N$. persculptus Biozone occurs within the Kuanyinchiao Bed at Wangjiawan (Chen et al., 2005b). Therefore, this second $\delta^{13} \mathrm{C}$ peak, appears to occur within the lower part of the $N$. persculptus Biozone.

Wang Kun et al. (1993) also reported a major positive carbon isotope excursion in the organic matter, occurring close to the base of the N. extraordinarius Biozone at Wangjiawan, Yichang, which is similar to our curve, despite the fact that the analyses were derived from weathered samples.

This positive $\delta^{13} \mathrm{C}$ excursion is widely regarded as resulting from the gradual growth of the ice sheet at the Ordovician South Pole region, followed by a rapid melting of the ice sheet (Brenchley et al., 1994, 1999; Sheehan, 2001). This indicates that the main phase of glaciation expansion began right before Hirnantian and finished before the end of Ordovician. In addition, as recorded in carbon isotope records from Arctic Canada (Melchin and Holmden, in press) and in the record of glacial sediments in North Africa (Ghienne, 2003), there appear to be at least two distinct, main pulses of glacial advance and retreat during the Hirnantian Stage. There is currently debate in the literature concerning the causal relationship between the variations in $\delta^{13} \mathrm{C}$ values and the glacial cycles. Whereas some authors suggest that the $\delta^{13} \mathrm{C}$ variations result from climatically driven changes in organic-matter productivity and burial patterns (e.g., Brenchley et al., 2003), others have suggested that changes in rates of carbonate platform weathering were an important factor in generating the regionally variable record of $\delta^{13} \mathrm{C}$ variation (e.g., Kump and Arthur, 1999; Kump et al., 1999; Melchin and Holmden, in press).

Brenchley et al. (2003) proposed that the major positive $\delta^{13} \mathrm{C}$ excursion in carbonates seen in Estonia and Latvia coincides with the base of the Hirnantian Stage and that the timing and shape of this curve could be used as a tool for precise global correlation of Hirnantian sequences. However, Melchin et al. (2003) and Melchin and Holmden (in press) provided evidence suggesting that the peak $\delta^{13} \mathrm{C}$ excursions observed at Dob's Linn (Underwood et al., 1997), Anticosti Island (Long, 1993), and in Estonia and Latvia (Brenchley et al., 2003) occurred in younger Hirnantian strata with weaker shifts in the lower Hirnantian. A detailed discussion of the global correlation of Hirnantian carbon isotope curves and causes of their regional variations is beyond the scope of this report. However, it is clear from these results that the Wangjiawan sections can provide a reliable record of $\delta^{13} \mathrm{C}$ variations through the Hirnantian that is broadly consistent with patterns seen in many other parts of the world. Both organic and inorganic carbon isotopic analyses possess good potential for testing and correlating the base of the N. extraordinarius Biozone although there may be some regional differences in timing and magnitude of these events.

\section{Acknowledgements}

The present research is supported by the Chinese Academy of Sciences (KZCX2-SW-129, KZCX3-SW-149) and the Ministry of Science and Technology (2001DEA20020-3). Mitchell's participation in this project was also supported by grant EAR 0107056 from the National Science Foundation.

\section{References}

Apollonov, M.K., Bandaletov, S.M. \& Nikitin, J.F. 1980. The OrdovicianSilurian Boundary in Kazakhstan: "Nauka" Kazakhstan SSR Publishing House: $1-232$.

Astini, R.A. 2003. Chapter 1: The Ordovician Proto-Andean Basins. Benedetto, J.L. (ed.): Ordovician Fossils of Argentina. Universidad Nacional De Córdoba, Secretarå de Ciencia y Technologåa, Córdoba, Argentina. 1-74

Bancroft, B.B. 1933. Correlation tables of the stages Costonian-Onnian in England and Wales. Blakeney, Gloucestershire: Privately printed: 1-4. 
Bassett, D.A., Whittington, H.B. \& Williams, A. 1966. The stratigraphy of the Bala district, Merionethshire. Journal of Geological Society London, 122: 219-271.

Benedetto, J.L. 1986. The first typical Hirnantia fauna from South America (San Juan Province, Argentine Precordillera). In Racheboeuf, P. \& Emig, C.C. (eds.): Les Brachiopodes Fossiles et Actuels. Biostratigraphie du Paleozoique, 4: 439-447.

Benedetto, J.L. 2003. Chapter 7: Brachiopods. In Benedetto, J.L. (ed.): Ordovician Fossils of Argentina. Universidad Nacional De Córdoba, Secretarå de Ciencia y Technologåa, Córdoba, Argentina. 187-272.

Benedetto, J.L., Sanchez, T.M., Carrera, M.G., Brussa, E.D. \& Salas, M.J. 1999. Paleontological constraints on successive paleogeographic positions of Precordillera terrane during the early Paleozoic. Geological Society of America Special Paper, 336: 21-42.

Bergström, J. 1968. Upper Ordovician brachiopods from Västergötland, Sweden. Geologica et Palaeontologica, 2: 1-35.

Bergström, S.M., Finney, S.C., Chen, X., Palsson, C., Wang, Z.-H. \& Grahn, Y. 2000. A proposed global boundary stratotype for the base of the Upper Series of the Ordovician System: The Fågelsång section, Scania, southern Sweden. Episodes, 23: 102-109.

Berry, W.B.N. \& Boucot, A.J. 1973. Glacio-eustatic control of late Ordovician-early Silurian platform sedimentation and faunal changes. Geological Society of America Bulletin, 84: 275-284.

Brenchley, P.J. 1984. Late Ordovician extinction and their relationship to the Gondwana glaciation. In Brenchley, P.J. (ed.): Fossils and Climate. Chichester, New York, Brisbane, Toronto, Singapore: John Wiley \& Sons: 291-316.

Brenchley, P.J. 1989. The Late Ordovician extinction. In Donovan, S.K. (ed.): Mass Extinction, chapter 6. Ferdinand Enke Verlag Stuttgart: 104-132.

Brenchley, P.J. 1998. The Hirnantian Boundary Stratotype: Ordovician News, 15: 14-15.

Brenchley, P.J., Marshall, J.D., Carden, G.A.F., Robertson, D.B.R., Long, D.G.F., Meidla, T., Hints, L., \& Anderson, T. 1994. Bathymetric and isotopic evidence for a short-lived Late Ordovician glaciation in a greenhouse period. Geology, 22: 295-298.

Brenchley, P.J., Carden, G.A., Hints, L., Kaljo, D., Marshall, J.D., Martma, T., Meidla, T. \& Nolvak, J. 2003. High-resolution stable isotope stratigraphy of Upper Ordovician sequences: Constraints on the timing of bioevents and environmental changes associated with mass extinction and glaciation: Bulletin of Geological Society of America, 115: 89-104.

Brussa, E.D., Mitchell, C.E. \& Astini, R.A. 1999. Ashgillian (Hirnantian?) graptolites from the western boundary of the Argentine Precordillera. Acta Univeritatis Carolinae-Geologica, 43: 199-202.

Buggish, W. \& Astini, R.A. 1993. The Late Ordovician ice age: new evidence from the Argentine Precordillera. In Findlay, R.H., Unrug, R., Banks, M.R. \& Veevers, J.J. (eds.): Gondwana Eight: Assembly, Evolution, and Dispersal. Balkima: Rotterdam: 439-447.

Chen, X., Fan, J.-X., Melchin, M.J. \& Mitchell, C.E. 2005a. Hirnantian (latest Ordovician) graptolites from the Upper Yangtze region, China. Paleontology, 48: 235-280.

Chen, X. \& Lenz, A.C. 1984. Correlation of Ashgill Graptolite faunas of Central China and Arctic Canada, with a Description of Diceratograptus cf. mirus $\mathrm{Mu}$ from Canada. In Nanjing Institute of geology and Palaeontology, Academia Sinica (ed.): Stratigraphy and Palaeontology of Systemic Boundaries in China, v. 1, Ordovician-Silurian Boundary. Hefei: Anhui Science and Technology Publishing House: 247-258.

Chen, X. \& Lin, Y.-K. 1984. On the material of Glyptograptus persculptus (Salter) from the Yangtze Gorges, China. In Nanjing Institute of Geology and Palaeontology, Academy Sinica (ed.): Stratigraphy and Palaeontology of Systemic Boundaries in China, v. 1, Ordovician-Silurian Boundary. Hefei: Anhui Science and Technology Publishing House: 191-200.

Chen, X., Melchin, M.J., Sheets, H.D., Mitchell, C.E. \& Fan, J.-X. 2005b. Patterns and processes of latest Ordovician graptolite extinction and recovery based on data from South China. Journal of Palaeontology, 79: $842-861$.

Chen, X. \& Rong, J.-Y. (eds.) 1996. Telychian (Llandovery) of the Yangtze Region and its Correlation with British Isles. Beijing: Science Press: 1-162 (in Chinese with English abstract).

Chen, X., Rong, J.-Y., Mitchell, C.E., Harper D.A.T., Fan, J.-X., Zhan, R.B., Zhang, Y.-D., Li, R.-Y. \& Wang, Y. 2000. Late Ordovician to earliest Silurian graptolite and brachiopod biozonation from the Yangtze region, South Chian with a global correlation. Geological Magazine, 137: $623-650$
Chen, X. \& Rong, J.-Y. 2002. A Proposal of the Candidate Section of the Base of the Silurian. Silurian Times, 10: 21-24.

Chen, X., Rong, J.-Y. \& Fan, J.-X. 2003. A proposal for a candidate section for restudy of the base of Silurian. In Ortega, G. \& Aceñolaza, G.F. (eds.): Proceedings of the 7 th International Graptolite Conference and Field meeting of the International Subcommission on Silurian Stratigraphy. INSUGEO Serie Correlación Geologica, 18: 119-123.

Cocks, L.R.M. \& Fortey, R.A. 1997. A new Hirnantia fauna from Thailand and the biogeography of the latest Ordovician of South-east Asia. Geobios, 20: 117-126.

Cooper, R.A. \& Sadler, P.M. 2004. Chapter 15: Ordovician System. In Gradstein, F.M., Ogg, J.G. \& Smith, A.G. (eds.): A Geologic Time Scale. Cambridge University Press: Cambridge: 165-187.

Cuerda, A.J., Rickards, R.B. \& Cingolani, C. 1988. A new Ordovician-Silurian boundary section in San Juan Province, Argentina, and its definitive graptolite fauna. Journal of the Geological Society of London, 145: 749-757.

Finney, S.C. 2005. Global Series and Stages for the Ordovician System: A progress Report. Geologica Acta, 3: 309-316.

Finney, S.C., Berry, W.B.N., Cooper, J.D., Ripperdan, R.L., Sweet, W.C., Jacobson, S.R., Soufiane, A., Achab, A. \& Noble, P.J. 1999. Late Ordovician mass extinction: A new perspective from stratigraphic sections in central Nevada. Geology, 27: 215-218.

Fortey, R.A., Harper, D.A.T., Ingham, J.K., Owen, A.W., Parkes, M.A., Rushton, A.W.A. \& Woodcock, N.H. 2000. A revised Correlation of Ordovician Rocks in the British Isles. The Geological Society Special Report, 24: 1-83.

Fortey, R.A., Harper, D.A.T., Ingham, J.K., Owen, A.W. \& Rushton, A.W.A. 1995. A revision of Ordovician series and stages from the historical type area. Geological Magzine, 132: 15-30.

Ghienne, J.-F. 2003. Late Ordovician sedimentary environments, glacial cycles, and post-glacial transgression in the Taoudeni Basin, West Africa. Palaeogeography, Palaeoclimatology, Palaeoecology, 189: $117-145$.

Goldman, D. 2003. The Diplacanthograptus caudatus Zone: a proposal for a new, global recognizable, Upper Ordovician graptolite zone. In Albanesi, G.L., Beresi, M.S. \& Peralta, S.H. (eds.): Ordovician from the Andes. INSUGEO Serie Correlación Geológica, 17: 65-70.

Gradstein, F.M., Ogg, J.G., Smith, A.G., Bleeker, W. \& Lourens, L.J. 2004 A new geologic time scale, with special reference to Precambrian and Neogene from the Dabie Mountains, central China. Episodes, 27: 83-100.

Gutiérrez-Marco, J.C., Robardet, M. \& Picarra, J.M. 1998. Silurian Stratigraphy and Paleogeography of the Iberian Peninsula (Spain and Portugal). In Gutiérrez-Marco, J.C. \& Robardet, M. (eds.): Proceedings of the Sixth International Graptolite Conference of the GWG(IPA) and the 1998 Field Meeting of the International Subcommission on Silurian Stratigraphy (ICS-IUGS). Instituto Tecnológico Geominero de España, Temas Geológico-Mineros, 23: 13-44.

Harper, D.A.T. 1981. The Stratigraphy and faunas of the Upper Ordovician High Mains Formation of the Girvan district. Scottish Journal of Geology, 17: 247-255.

Harper, D.A.T. \& Rong, J.-Y. 1995. Patterns of change in the brachiopod faunas through the Ordovician-Silurian interface. Modern Geology, 20: 83-100.

Harper, D.A.T. \& Williams, S.H. 2002. A relict Ordovician brachiopod fauna from the Parakidograptus acuminatus Biozone (lower Silurian) of the English Lake District. Lethaia, 35: 71-78.

Ingham, J.K. \& Wright, A.D. 1970. A revised classification of the Ashgill Series: Lethaia, 3: 233-242.

Jaeger, H. 1977. Graptolites. The Silurian-Devonian Boundary. IUGS Series, A: 337-345.

Jaeger, H. 1988. The Ordovician-Silurian boundary in the Saxothuringian Zone of the Variscan Orogen. In Cocks, L.R.M. \& Rickards, R.B. (eds.): A global analysis of the Ordovician-Silurian boundary. Bulletin British Museum (Natural History) Geology, 43: 101-106.

Jones, C.R. 1973. The Silurian-Devonian graptolite faunas of the Malay Peninsula. Natural Environment Research Council, Institute of Geological Sciences, Overseas Geology and Mineral Resources, 44: 1-28.

Koren', T.N. \& Bjerreskov, M. 1997. Early Llandovery monograptids from Bornholm and the southern Urals: taxonomy and evolution. Bulletin of the Geological Society of Denmark, 44: 1-43.

Koren', T.N. \& Melchin, M.J. 2000. Lowermost Silurian Graptolites from the Kurama Range, eastern Uzbekistan. Journal of Paleontology, 74: 1093-1113. 
Koren' T.N. \& Nikitin, I.F. 1982. Graptolites about the Ordovician-Silurian boundary. Comments on Report No. 45, Ordovician-Silurian Boundary Working Group (unpublished)

Koren', T.N., Oradovskaya, M.M. \& Sobolevskaya, R.F. 1988. The Ordovician-Silurian boundary beds of the north-east USSR. in Cocks, L.R.M. \& Rickards, R.B. (eds.): A global analysis of the OrdovicianSilurian boundary. Bulletin British Museum (Natural History) Geology, 43: $133-138$.

Koren', T.N., Oradovskaya, M.M., Sobolevskaya, R.F., Pyma, L.J. \& Sobolevskaya, R.F. 1983. The Ordovician and Silurian boundary in the northeast of the USSR. Trudy Mezhvedomstvennogo Stratigraficheskogo Komiteta SSSR, 11: 1-205.

Koren', T.N., Sobolevskaya, R.F., Mikhailova, N.F. \& Tasi, D.T. 1979. New evidence on graptolite succession across the Ordovician-Silurian Boundary in the Asian part of the USSR. Acta Palaeontologica Polonica, 24: 125-136.

Kump, L.R. \& Arthur, M.A. 1999. Interpreting carbon-isotope excursions: carbonates and organic matter. Chemical Geology, 161: 181-198.

Kump, L.R., Arthur, M.A., Patzkowski, M.E., Gibbs, M.T., Pinkus, D.S. \& Sheehan, P.M. 1999. A weathering hypothesis for glaciation at high atmospheric pCO2 during the Late Ordovician. Palaeogeography, Palaeoclimatology, Palaeoecology, 152: 173-187.

Legrand, P. 1988. The Ordovician-Silurian boundary in the Algerian Sahara. Bulletin of British Museum of Natural History (Geology), 43: 171-176.

Lenz, A.C. \& McCracken, A.D. 1982. The Ordovician-Silurian boundary, northern Canadian Cordillera: graptolite and conodont correlation. Canadian Journal of Earth Sciences, 19: 1308-1322.

Lenz, A.C. \& McCracken, A.D. 1988. Ordovician-Silurian boundary, northern Yukon. In Cocks, L.R.M. \& Rickards, R.B. (eds.): A global analysis of the Ordovician-Silurian boundary. Bulletin British Museum (Natural History) Geology, 43: 265-271.

Leone, F., Hammann, W., Laske, R., Serpagli, E. \& Villas, E. 1991. Lithostratigraphic units and biostratigraphy of the post-sardic Ordovician sequence in south-west Sardinia. Bollettino della Società Paleontologica Italiana, 30: 201-235.

Lesperance, P.J. \& Sheehan, P.M. 1976. Brachiopods from the Hirnantian stage (Ordovician-Silurian) at Percé, Quebec. Palaeontology, 19: 719-731.

Lin, Y.-K. \& Chen, X. 1984. Glyptograptus persculptus zone - the Earliest Silurian graptolite zone from Yangtze Gorges, China. In Nanjing Institute of Geology and Palaeontology (ed.): Stratigrapghy and Palaeontology of Systemic Boundaries in China, v. 1, Ordovician - Silurian Boundary. Hefei: Anhui Science and Technology Publishing House: 203-232.

Long, D.G.F. 1993. Oxygen and carbon isotopes and event stratigraphy near the Ordovician-Silurian boundary, Anticosti Island, Quebec. Palaeogeography, Palaeoclimatology, Palaeoecology, 104: 49-59.

Marek, L. \& Havlíč ek, V. 1967. The articulate brachiopods of the Kosov Formation (Upper Ashgillian). Vìstnik Ústøedniho Ustavu Geologicko, 57: 231-236.

Melchin, M.J., Holmden, C. \& Williams, S.H. 2003. Correlation of graptolite biozones, chitinozoan biozones, and carbon isotope curves through the Hirnantian. In Albanesi, G.L., Beresi, M.S. \& Peralta, S.H. (eds.): Ordovician from the Andes. INSUGEO Serie Correlación Geologica, 17: 101-104.

Melchin, M.J., McCracken, A.D. \& Oliff, F.J. 1991. The Ordovician-Silurian boundary on Cornwallis and Truro islands, Arctic Canada: preliminary data. Canadian Journal of Earth Sciences, 28: 1854-1862.

Melchin, M.J. \& Mitchell, C.E. 1991. Late Ordovician extinction in the Graptoloidea. In Barnes, C.R. \& Williams, S.H. (eds.): Advances in Ordovician Geology. Geological Survey of Canada Paper, 90-9: 143-156.

Mitchell, C.E., Melchin, M.J., Sheets, H.D., Chen, X. \& Fan, J.-X. 2003. Was the Yangtze Platform a refugium for graptolites during the Hirnantian (Late Ordovician) mass extinction? In Albanesi, G.L., Beresi, M.S. \& Peralta S.H. (eds.): Ordovician from the Andes. INSUGEO Serie Correlación Geológica , 17: 523-526.

Mu, E.-Z., Li, J.-J., Ge, M.-Y., Chen, X., Lin, Y.-K. \& Ni, Y.-N. 1993. Upper Ordovician Graptolites of Central China region. Palaeontologia Sinica, B29: 1-393 (in Chinese with English summary).

Mu, E.-Z. \& Lin, Y.-K. 1984. Graptolites from the Ordovician-Silurian Boundary Sections of Yichang Area, W Hubei. In Nanjing Institute of Geology and Palaeontology (ed.): Stratigrapghy and Palaeontology of
Systemic Boundaries in China, v. 1, Ordovician - Silurian Boundary. Hefei: Anhui Science and Technology Publishing House: 45-82.

Mu, E.-Z. \& Ni, Y.-N. 1983. Uppermost Ordovician and Lowermost Silurian graptolites from the Xainza area of Xizang (Tibet) with discussion on the Ordovician-Silurian boundary. Palaeontologia Cathyana, 1: 151-179.

Mu, E.-Z., Zhu, Z.-L., Lin, Y.-K. \& Wu, H.-J. 1984. The Ordovician-Silurian Boundary in Yichang, Hubei. In Nanjing Institute of Geology and Palaeontology (ed.): Stratigrapghy and Palaeontology of Systemic Boundaries in China, v. 1, Ordovician-Silurian Boundary. Hefei: Anhui Science and Technology Publishing House: 15-44.

Rickard, R.B. 2002. The graptolitic age of the type Ashgill Series (Ordovician), Cumbria, UK. Proceedings of the Yorkshire Geological Society, 54: $1-16$.

Rickards, R.B., Brussa, E.D., Toro, B.A. \& Ortega, G. 1996. Ordovician and Silurian graptolite assemblages from Cerro del Fuerte, San Juan Province, Argentina. Geological Journal, 31: 101-122.

Rong, J.-Y. 1979. The Hirnantia Fauna of China with the comments on the Ordovician-Silurian Boundary. Acta Stratigraphica Sinica, 3: 1-29.

Rong, J.-Y. 1984a. Distribution of the Hirnantia fauna and its meaning. In Bruton, D.L. (ed.): Aspects of the Ordovician System. Palaeontological Contributions from the University of Oslo, 295: 101-112.

Rong, J.-Y. 1984b. Brachiopods of latest Ordovician in the Yichang District, western Hubei, Central China. In Nanjing Institute of Geology and Palaeontology, Academia Sinica (ed.): Stratigraphy and Palaeontology of Systemic Boundaries in China, v. 1, Ordovician-Silurian Boundary. Hefei: Anhui Science and Technology Publishing House: 111-176.

Rong, J.-Y., Chen, X. \& Harper, D.A.T. 2002. The latest Ordovician Hirnantia Fauna (Brachiopoda) in time and space. Lethaia, 35: 231-249.

Rong, J.-Y., Chen, X., Harper, D.A.T. \& Mitchell, C.E. 1999. Proposal of a GSSP candidate section in the Yangtze Platform region, S. China, for a new Hirnantian boundary stratotype. Acta Universitatis Carolinae-Geologica, 43: 77-80.

Rong, J.-Y. \& Harper, D.A.T. 1988. A global synthesis of the latest Ordovician Hirnantian brachiopod faunas. Transactions of the Royal Society of Edinburgh Earth Science, 79: 383-402.

Rong, J.-Y. \& Xu, H.-K. 1987. Terminal Ordovician Hirnantia Fauna of the Xainza District, Northern Xizang. Bulletin of Nanjing Institute of Geology and Palaeontology, Academia Sinica, 11: 16-56 (in Chinese).

Ross, R.J. Jr \& Naeser, C.W. 1984. The Ordovician time scale - New refinements. In Bruton, D.L. (ed.): Aspects of the Ordovician System. Palaeontological Contributions from the University of Oslo, 295: 5-10.

Schauer, M. 1971. Biostratigraphie und taxionomie der Graptolithen des tieferen Silurs unter besonderer Berucksichtigung der tektonischen Deformation. Freiberger Forschungshefte, C273 Palaeontologie: 1-94.

Sheehan, P.M. 1973. The relation of late Ordovician glaciation to the Ordovician-Silurian changeover in North American brachiopod faunas. Lethaia, 6: 147-154.

Sheehan, P.M. 2001. The Late Ordovician mass extinction. Annual Reviews of Earth and Planetary Sciences, 29: 331-364.

Sobolevskaya, R.F. 1974. New Ashgill graptolites in the middle flow basin of the Kolyma-river. In Obut, A.M. (ed.): Graptolites of the USSR. Nauka Siberian Branch Novosibirsk: 63-71 (in Russian).

Storch, P. 1988. The Ordovician-Silurian boundary in the Prague Basin, Bohemia. Bulletin of British Museum Natural History (Geology), 43: 95-100.

Štorch, P. \& Leone, F. 2003. Occurrence of the late Ordovician (Hirnantian) graptolite Normalograptus ojsuensis (Koren \& Michaylova, 1980) in south-western Sardinia, Italy. Paleontologica Italiana, 42: 31-38.

Storch, P. \& Loydell, D.K. 1996. The Hirnantian Graptolites Normalograptus persculptus and 'Glyptograptus' bohemicus: Stratigraphical consequences of their synonymy. Palaeontology, 39: 869-881.

Štorch, P. \& Serpagli, E. 1993. Lower Silurian Graptolites from Southwestern Sardinia. Bollettino della Societa Paleontologica Italiana, 32: 3-57.

Sutcliffe, O.E., Harper, D.A.T., Salem, A.A., Whittington, R.J. \& Craig, J. 2001. The development of an atypical Hirnantia-brachiopod fauna and the onset of glaciation in the late Ordovician of Gondwana. Transactions of the Royal Society of Edinburgh, Earth Sciences, 92: 1-14.

Teller, L. 1969. The Silurian biostratigraphy of Poland based on graptolites. Acta Geologica Polonica, 19: 399-501.

Temple, J.T. 1965. Upper Ordovician brachiopods from Poland and Britain. Acta Palaeontologica Polonica, 10: 379-450.

Underwood, C.J., Crowley, S.F., Marshall, J.D. \& Brenchley, P.J. 1997. High-resolution carbon isotope stratigraphy of the basal Silurian Strato- 
type (Dob's Linn, Scotland) and its global correlation. Journal of the Geological Society London, 154: 709-718.

Underwood, C.J., Deynoux, M. \& Ghienne, J-F. 1998. High palaeolatitute (Hodh, Mauritania) recovery of graptolite faunas after the Hirnantian (end Ordovician) extinction event. Palaeogeography, Palaeoclimatology, Palaeoecology, 142: 91-105.

Villas, E., Lorenzo, S. \& Gutiérrez-Marco, J.C. 1999. First record of a Hirnantia Fauna from Spain, and its contribution to the Late Ordovician palaeogeography of northern Gondwana. Transactions of the Royal Society of Edinburgh, Earth Sciences, 89: 187-197.

Wang, K., Orth, C.J., Moses, A. Jr, Chatterton, B.D.E., Wang, X.-F. \& Li, J.-J. 1993. The great latest Ordovician extinction on the South China Plate: Chemostratigraphic studies of the Ordovician - Silurian boundary interval on the Yangtze Platform. Palaeogeography, Paleoclimatology, Palaeoecology, 104: 61-79.

Wang, X.-F., Hoffknecht, A., Xiao, J.-X., Li, Z.-H., Chen, S.-Q., Brocke, R., Erdtmann, B.-D. 1993. Thermal maturity of the Sinian and Early Paleozoic in West Hubei, China, assessed by CAI, reflectances, and geochemical studies. Stratigraphy and Palaeontology of China, 2: 19-45.

Wang, X.-F., Ni, S.-Z., Zeng, Q.-L., Xu, G.-H., Zhou, T.-M., Li, Z.-H., Xiang, L.-W. \& Lai, C.-G. 1987. Biostratigraphy of the Yangtze Gorge area 2: Early Palaeozoic Era. Beijing: Geological Publishing House: 1-641 (in Chinese).

Wang, X.-F., Zeng, Q.-L., Zhou, T.-M., Ni, S.-Z., Xu, G.-H., Sun, Q.-Y., Li, Z.-H., Xiang, L.-W. \& Lai, C.-G. 1983. Latest Ordovician and Earliest Silurian Faunas from the eastern Yangzi Gorges, China, with comments on Ordovician-Silurian Boundary. Bulletin of the Yichang Institute of Geology and Mineral Resources, Academy of Geological Sciences, 6: 95-163 (in Chinese with English abstract).

Webby, B.D. 1998. Steps toward a global standard for Ordovician stratigraphy. Newsletter on Stratigraphy, 36:1-33.

Webby, B.D. 2004. Introduction. In Webby, B.D., Paris, F., Droser, M.L., and Percival, I.C. (eds.), The Great Ordovician Biodiversification Event. 1-40. Columbia University Press, New York.

Webby, B.D., Cooper, R.A., Bergström, S.M. \& Paris, F. 2004. Stratigraphic Framework and Time Slices. In Webby, B.D., Paris, F., Droser, M.L. \& Percival, I.C. (eds.): The Great Ordovician Biodiversification Event. Columbia University Press: New York: 41-47.

Whittington, H.B. \& Williams, A. 1964. The Ordovician period. Quarterly Journal of the Geological Society London, 120: 241-254.

Williams, A., Strachan, I., Bassett, D.A., Dean, W.T., Ingham, J.K., Wright, A.D. \& Whittington, H.B. 1972. A Correlation of Ordovician rocks in the British Isles. Special Report of the Geological Society London, 3: 1-74.

Williams, S.H. 1988. Dob's Linn - the Ordovician-Silurian Boundary Stratotype. In Cocks, L.R.M. \& Rickards, R.B.(eds.): A Global Analysis of the Ordovician-Silurian boundary. Bulletin British Museum (Natural History) Geology Series, 43: 17-30.

Wright, A.D. 1968. A westward extension of the Upper Ashgillian Hirnantia fauna. Lethaia, 1: 352-367.

Zhu, Z.-L. \& Wu, H.-J. 1984. The Dalmanitian fauna (trilobite) from Huanghuachang and Wangjiawan, Yichang County, Hubei Province. In Nanjing Institute of Geology and Palaeontology (ed.): Stratigraphy and Palaeontology of Systemic boundaries in China, v. 1, Ordovician-Silurian boundary. Hefei: Anhui Sciences and Technology Publishing House: 83-104.
Prof. Xu Chen, born in 1936. Research professor of the Nanjing Institute of Geology and Palaeontology from 1989. Vice Chairman of the International Subcommission on Ordovician Stratigraphy (1991-2003) and Chairman of the Subcommission from 2003. Main research interests are Ordovician and Silurian stratigraphy and graptolites.

Prof. Jiayu Rong, born in Dec. of 1941. Research professor in paleontology and biostratigraphy. Chairman of the International Subcommission on Silurian Stratigraphy (2000-). His research focuses mainly on brachiopod systematics, community paleoecology, paleobiogeography and biostratigraphy of the Ordovician, Silurian and Lower Devonian.

Dr. Junxuan Fan, born in October of 1973. Associate research professor in paleontology and stratigraphy. His research interests include quantitative analysis on Ordovician and Silurian paleontology and stratigraphy, graptolite systematics, and paleobiodiversity database.
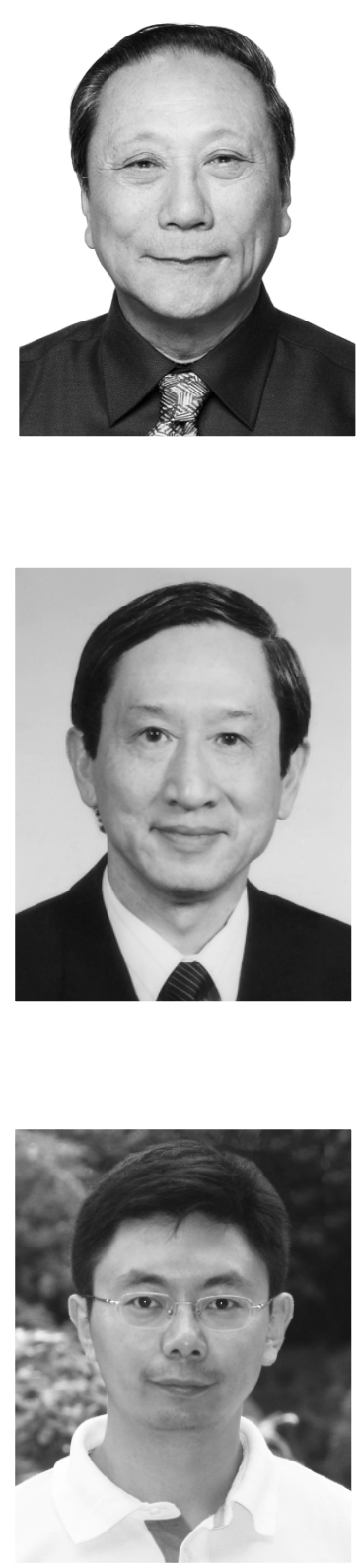